\title{
Rationalisation of Patterns of Competing Reactivity by X-ray Structure Determination: Reaction of Isomeric (Benzyloxythienyl)oxazolines with a Base
}

\author{
R. Alan Aitken *(D), Andrew D. Harper and Alexandra M. Z. Slawin (D)
}

check for

updates

Citation: Aitken, R.A.; Harper, A.D.; Slawin, A.M.Z. Rationalisation of

Patterns of Competing Reactivity by X-ray Structure Determination:

Reaction of Isomeric

(Benzyloxythienyl)oxazolines with a Base. Molecules 2021, 26, 7690.

https://doi.org/10.3390/

molecules 26247690

Academic Editor: Miriam Rossi

Received: 27 October 2021

Accepted: 16 December 2021

Published: 20 December 2021

Publisher's Note: MDPI stays neutral with regard to jurisdictional claims in published maps and institutional affiliations.

Copyright: (C) 2021 by the authors. Licensee MDPI, Basel, Switzerland. This article is an open access article distributed under the terms and conditions of the Creative Commons Attribution (CC BY) license (https:/ / creativecommons.org/licenses/by/ $4.0 /)$.
EaStCHEM School of Chemistry, University of St Andrews, North Haugh, St Andrews KY16 9ST, Fife, UK; andydharper@hotmail.com (A.D.H.); amzs@st-and.ac.uk (A.M.Z.S.)

* Correspondence: raa@st-and.ac.uk; Tel.: +44-1334-463865

\begin{abstract}
Three isomeric (benzyloxythienyl)oxazolines 9, 11 and $\mathbf{1 3}$ have been prepared and are found, upon treatment with a strong base, to undergo either Wittig rearrangement or intramolecular attack of the benzylic anion on the oxazoline function to give products derived from cleavage of the initially formed 3-aminothienofuran products. This pattern of reactivity is directly linked to the distance between the two reactive groups as determined by $\mathrm{X}$-ray diffraction, with the greatest distance in $\mathbf{1 1}$ leading to exclusive Wittig rearrangement, the shortest distance in $\mathbf{1 3}$ giving exclusively cyclisation-derived products, and the intermediate distance in 9 leading to both processes being observed. The corresponding $N$-butyl amides were also obtained in two cases and one of these undergoes efficient Wittig rearrangement leading to a thieno[2,3-c]pyrrolone product.
\end{abstract}

Keywords: oxazoline; Wittig rearrangement; thiophene; thieno[2,3-c]pyrrolone; $\mathrm{X}$-ray structure

\section{Introduction}

Some time ago we described the reaction of 2-(2-benzyloxyphenyl)oxazoline 1 with a strong base to give either the 3 -aminobenzofuran product 2 resulting from intramolecular nucleophilic ring-opening of the oxazoline by the benzyl anion, or the oxazoline 3 in which the benzyloxy group has undergone a Wittig rearrangement (Scheme 1) [1]. Heterocycle formation by cyclisation of an aryloxy carbanion onto an ortho functional group is rather uncommon but formation of 3-aminobenzofurans by the so-called Gewald reaction of benzonitriles provides one example [2]. Similarly, although the Wittig rearrangement has been known for almost a century [3], it is not commonly used in synthesis and a recent review shows rather limited developments over the last 20 years [4]. While the aminobenzofuran formation could be optimised by using 3.3 equiv. of Schlosser's base $(n-\mathrm{BuLi} / t-\mathrm{BuOK})$ and applied to a number of substituted examples [1], the Wittig rearrangement process was not so favourable and, under optimal conditions of 2.2 equiv. butyllithium ( $n$-BuLi) in THF, an isolated yield of just $29 \%$ was obtained. As will shortly be reported elsewhere, the $\mathrm{N}$-butyl amide group is a more effective promoter of the Wittig rearrangement and treating compound 4 with 3.3 equiv. $n$-BuLi in THF gives almost entirely the rearranged product 5 , conveniently isolated as the phthalide 6 after acid-mediated cyclisation in $90 \%$ yield. However in the latter study, simply changing to the $N, N$-diisopropyl amide 7 and treating with 2.2 equiv. $n$-BuLi in toluene again resulted in cyclisation to give the 3 -aminobenzofuran 8 . It is clear from these studies that there is a delicate balance between Wittig rearrangement of the benzyloxy group without affecting the adjacent activating group, and interaction of the two groups with the formation of a furan ring. 


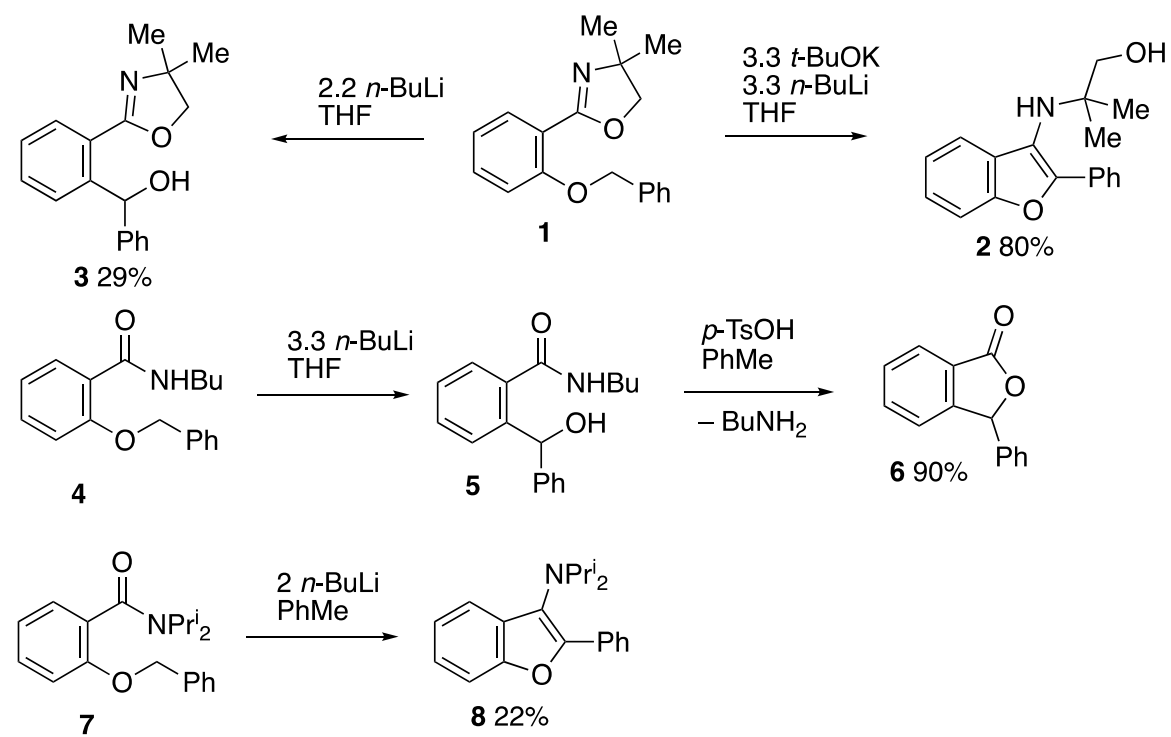

Scheme 1. Competition between Wittig rearrangement and cyclisation in benzene-based systems.

In contrast to the symmetrical benzene ring, the different adjacent positions on a heterocycle such as thiophene are not equivalent and so a more interesting pattern of reactivity can be expected, which would also lead to some unusual and novel heterocyclic products. In this paper, we report the synthesis, characterisation and reactivity upon treatment with a strong base, of the three isomeric (benzyloxythienyl)oxazolines 9, 11 and 13 (Scheme 2) as well as the corresponding (benzyloxythienyl)-N-butylcarboxamides 10, 12 and 14. As well as examining the pattern of reactivity we were interested to discover whether there was any correlation between this and the distance between the two adjacent groups as determined by X-ray diffraction.<smiles>CC1(C)COC(c2sccc2OCc2ccccc2)=N1</smiles>

9<smiles>CCCCNC(=O)c1sccc1OCc1ccccc1</smiles>

10<smiles>CC1(C)COC(c2ccsc2OCc2ccccc2)=N1</smiles><smiles>CCCCNC(=O)c1ccsc1OCc1ccccc1</smiles>

12<smiles>CC1(C)COC(c2cscc2OCc2ccccc2)=N1</smiles>

13<smiles>CCCCNC(=O)c1cscc1OCc1ccccc1</smiles>

14

Scheme 2. The six isomeric thiophene compounds targeted for reactivity studies.

\section{Results}

\subsection{Synthesis of 3-Benzyloxy-2-thienyl Systems $\mathbf{9}$ and $\mathbf{1 0}$}

O-Benzylation of the commercially available methyl ester $\mathbf{1 5}$ followed by ester hydrolysis of $\mathbf{1 6}$ gave the carboxylic acid $\mathbf{1 7}$ (Scheme 3). This was readily converted into the corresponding acid chloride which was reacted immediately with 2-amino-2-methylpropan1-ol to give the hydroxy amide 18 , which was cyclised using thionyl chloride to give the target oxazoline $\mathbf{9}$ in good overall yield. Alternatively, treating acid $\mathbf{1 7}$ with thionyl chloride followed by an excess of butylamine gave the target amide $\mathbf{1 0}$ also in high yield. 


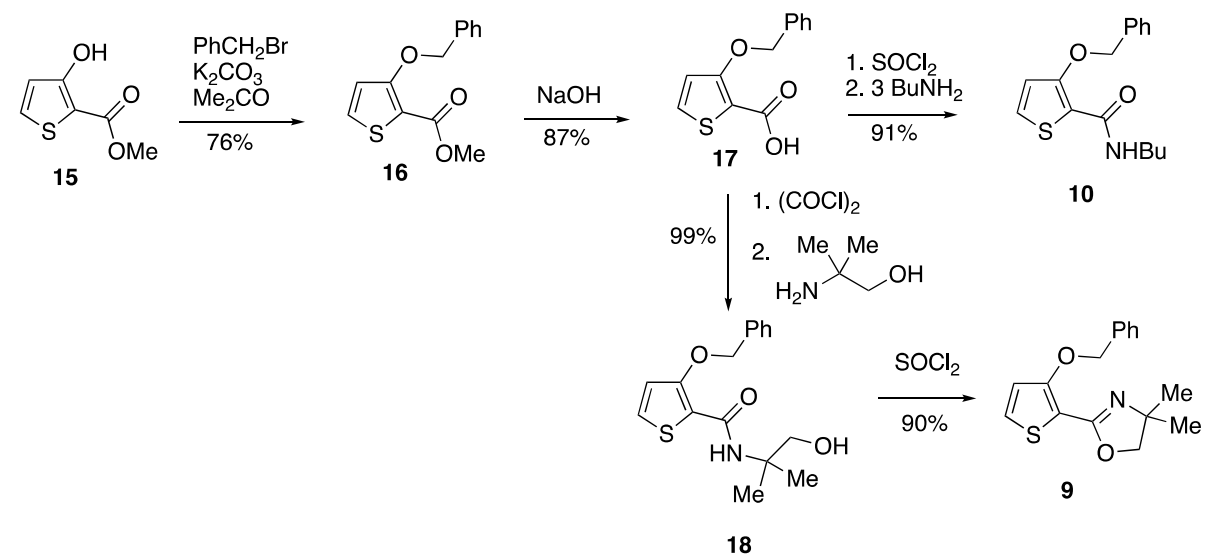

Scheme 3. Synthesis of 3-benzyloxy-2-thienyl compounds $\mathbf{9}$ and $\mathbf{1 0 .}$

\subsection{Reaction 3-Benzyloxy-2-thienyl Systems $\mathbf{9}$ and $\mathbf{1 0}$ with Base}

When compound $\mathbf{9}$ was subjected to the same conditions used to convert $\mathbf{1}$ into $\mathbf{2}$, a mixture of two products was formed which were separated by preparative thin-layer chromatography (TLC) on alumina and identified as the expected Wittig rearrangement product 19 , formed in $8 \%$ yield, and a second more major product $(43 \%)$ which was initially thought to be the expected cyclisation product 21 (Scheme 4). However certain features of the spectra were not consistent with this, notably the non-equivalence of the two methyl groups and $\mathrm{CH}_{2} \mathrm{O}$ hydrogens which suggested the presence of a stereogenic centre. After further evidence from ${ }^{13} \mathrm{C}$ and $2 \mathrm{D}$ NMR studies suggested the presence of a 2-alkylidenethiophen-3(2H)-one structure, and the HRMS result showed the presence of an extra oxygen atom as compared to $\mathbf{2 1}$, the actual structure was finally confirmed as the unusual morpholine-containing thiophenone 20 by $\mathrm{X}$-ray diffraction.<smiles>CC1(C)COC(c2sccc2OCc2ccccc2)=N1</smiles><smiles>[O-][N+](CO)Nc1c(-c2ccccc2)oc2ccsc12</smiles>

21

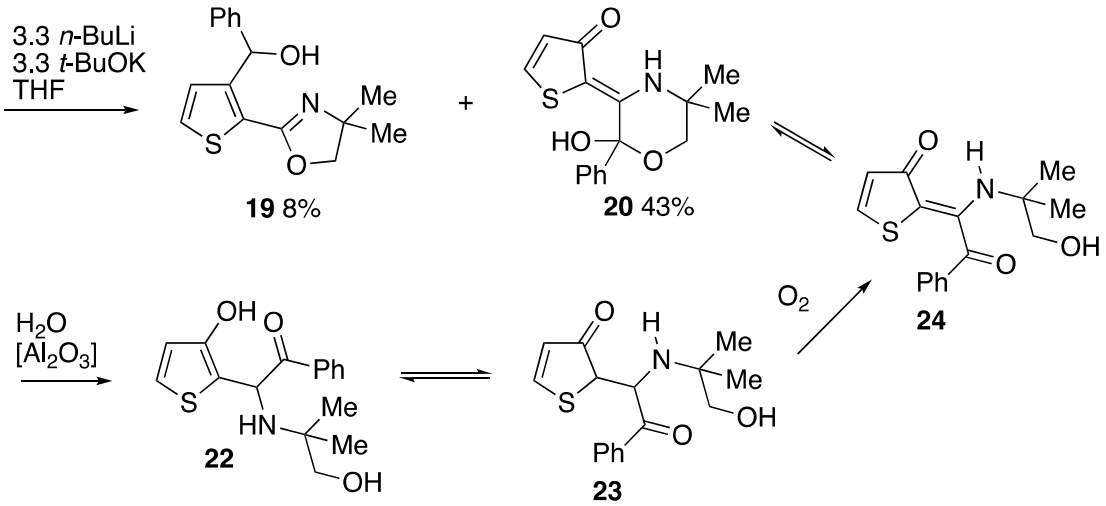

Scheme 4. Reaction of oxazoline 9 with $n$-BuLi/t-BuOK.

The molecular structure of $\mathbf{2 0}$ features two independent molecules in the unit cell in addition to one molecule each of $\mathrm{CH}_{2} \mathrm{Cl}_{2}$ and acetone. The two molecules are actually enantiomers and they both take up half chair conformations with the ring oxygen out of the plane, the $\mathrm{NH}$ in the plane and one methyl axial and one equatorial (Figure 1). Where they differ is that one has phenyl axial and $\mathrm{OH}$ equatorial while for the other it is the opposite way round.

In the crystal, there is hydrogen bonding both intramolecularly between the $\mathrm{NH}$ and $\mathrm{C}=\mathrm{O}$ and intermolecularly between $\mathrm{C}=\mathrm{O}$ and $\mathrm{OH}$; in terms of the Etter-Bernstein graph-set descriptors [5] $C^{1}{ }_{1}(7)[S(6)]$. The intermolecular interaction involves the two enantiomeric molecules alternating and the pattern is shown schematically in Figure 2 with parameters in Table 1. 

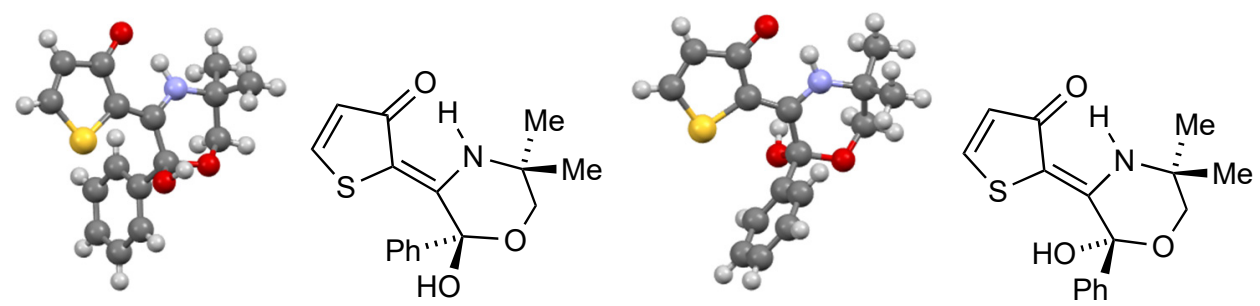

Figure 1. Conformations of the two enantiomeric molecules of 20 in the crystal.

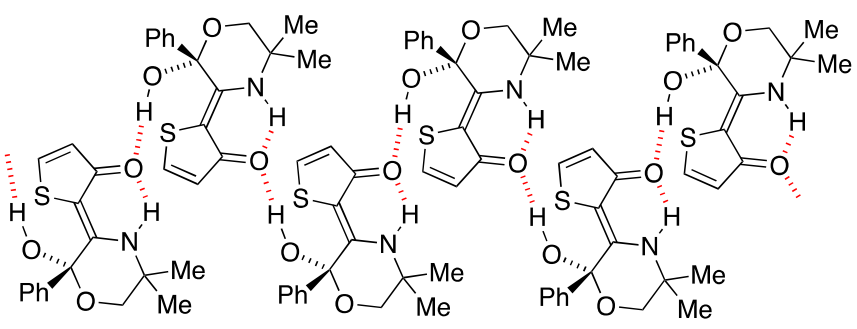

Figure 2. Schematic representation of the hydrogen bonding pattern for $\mathbf{2 0 .}$

Table 1. Hydrogen bonding parameters for $\left.20(\AA)^{\circ}\right)$.

\begin{tabular}{ccccc}
\hline D-H...A & D-H & H...A & D...A & D-H...A \\
\hline $\mathrm{O}(7)-\mathrm{H}(7) \ldots \mathrm{O}(23)$ & $0.98(7)$ & $1.61(7)$ & $2.592(6)$ & $177(7)$ \\
$\mathrm{N}(9)-\mathrm{H}(9) \ldots \mathrm{O}(3)$ & $0.98(6)$ & $1.74(7)$ & $2.649(6)$ & $153(7)$ \\
$\mathrm{O}(27)-\mathrm{H}(27) \ldots \mathrm{O}(3)$ & $0.98(5)$ & $1.72(5)$ & $2.694(6)$ & $173(6)$ \\
$\mathrm{N}(29)-\mathrm{H}(29) \ldots \mathrm{O}(23)$ & $0.98(5)$ & $1.70(5)$ & $2.584(6)$ & $147(5)$ \\
\hline
\end{tabular}

Once the structure of $\mathbf{2 0}$ was clear, its formation could be rationalised as shown in Scheme 4 by initial cyclisation of 9 to give the thieno[3,2-b]furan product 21 and hydrolysis of this on the alumina with opening of the furan ring to give 22, which in its thiophen-3-one tautomeric form can be oxidised by air to form the favourable fully conjugated ene-dione structure 24, which then cyclises to form the cyclic hemiketal 20. It should be noted that compound $\mathbf{2 0}$ was found to be quite unstable and although it was isolated in small amount with sufficient purity for identification, further attempts at purification resulted in decomposition. As described in a recent review [6], thiophene-based $o$-quinomethane analogues have a rich and varied chemistry, however, the formation of such a structure by hydrolysis then oxidation of a thieno[3,2-b]furan is unprecedented.

We now turned to the $N$-butyl amide $\mathbf{1 0}$ and found a much simpler pattern of reactivity. Treatment of $\mathbf{1 0}$ with $n$-BuLi under the standard conditions developed in the benzene series, resulted in exclusive Wittig rearrangement to give secondary alcohol 25 which could be characterised spectroscopically but was converted for isolation into the stable thieno[2,3-c]pyrrolone product 26 by treatment with $p$-toluenesulfonic acid in boiling toluene (Scheme 5) [7]. This method was also used to obtain stable cyclic products in the benzene-based systems, however, note that while 5 and analogues cyclise to lactones 6 with loss of butylamine, here we have a loss of water to form the lactam in excellent yield. The synthesis and chemistry of thieno[c]pyrrolones and their dihydro analogues has been recently reviewed [8].

Since such fused-ring heterocycles are rather uncommon we took the chance to determine the X-ray structure of compound 26 (Scheme 5). Only one previous X-ray structure of a compound with this ring system appears to have been published, that of the compound with butyl replaced by quinolin-8-yl [9], but the molecular dimensions are very similar. Interestingly the tert-butyl amide $\mathbf{2 7}$ isomeric with 25 has been prepared by ortho-directed metalation of $N$-tert-butylthiophene-2-carboxamide with $n$-BuLi followed by reaction with benzaldehyde [10]. 


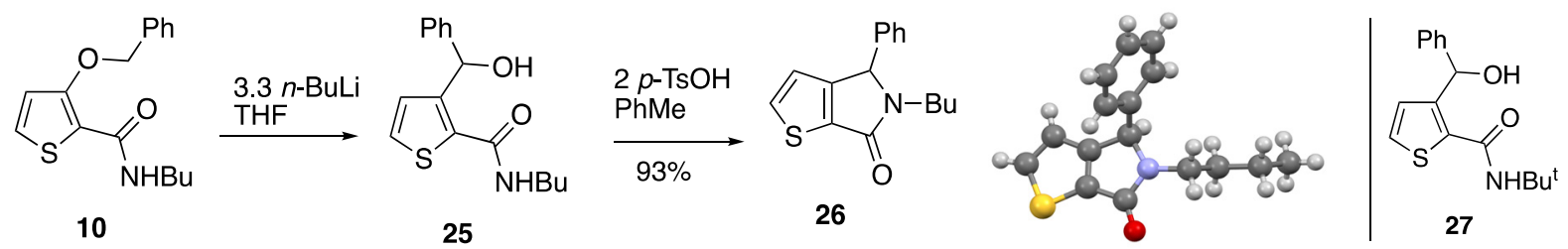

Scheme 5. Reaction of $\mathbf{1 0}$ with $n$-BuLi to give $\mathbf{2 5}$ and $\mathbf{2 6}$ and structure of an analogous product $\mathbf{2 7 .}$

\subsection{Synthesis of 2-Benzyloxy-3-thienyl Systems $\mathbf{1 1}$ and $\mathbf{1 2}$}

Entry to this system was gained by starting with the 3-thienyloxazoline 28 and introducing oxygen functionality at the 2-position by lithiation and treatment with bis(trimethylsilyl) peroxide (Scheme 6). As we have described in detail elsewhere [11], the resulting product had the 3-(oxazolidin-2-ylidene)thiophen-2-one structure 29 which exhibited an interesting and varied pattern of reactivity. However, for the present purpose, it could be cleanly O-benzylated in moderate yield to give the desired compound $\mathbf{1 1}$.
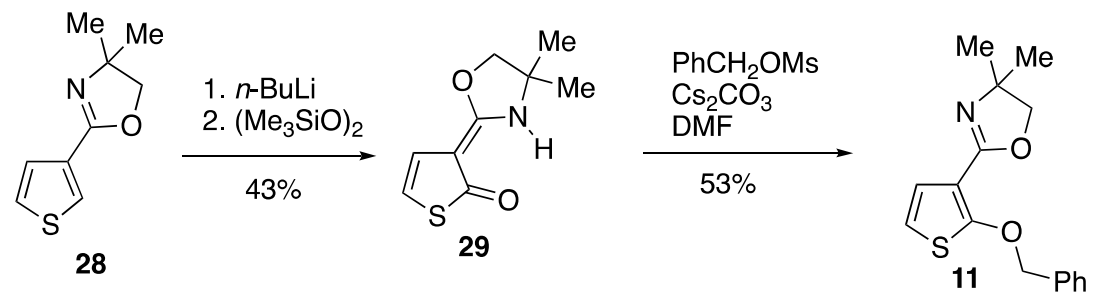

Scheme 6. Synthesis of oxazoline 11.

As described below, attempted application of a similar method to the formation of the amide 12 failed since lithiation of the corresponding $N$-butyl amide 32 followed by treatment with bis(trimethylsilyl) peroxide instead gave the silyl compound 33.

\subsection{Reaction of 2-Benzyloxy-3-thienyl Systems $\mathbf{1 1}$ and $\mathbf{1 2}$ with Base}

Treatment of oxazoline 11 with $n$-BuLi under the standard conditions developed for ring closure of $\mathbf{1}$ to give $\mathbf{2}$ gave exclusively the Wittig rearrangement product $\mathbf{3 0}$ in good yield (Scheme 7).<smiles>CC1(C)COC(c2ccsc2OCc2ccccc2)=N1</smiles>
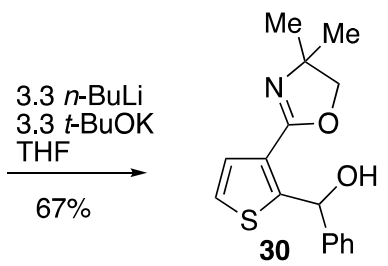

Scheme 7. Wittig rearrangement of oxazoline 11.

Although attempts to prepare the amide 12 by lithiation and bis(trimethylsilyl) peroxide treatment failed, instead giving the new silane 33 (Scheme 8), the expected Wittig rearrangement product from 12, compound 34 , was prepared by lithiation and benzaldehyde treatment of 32. It was not isolated, however, the reaction product was directly treated with $p$-toluenesulfonic acid giving the thieno[2,3-c]pyrrolone [8] product 35 isomeric with 26 together with a low yield of the oxidation product $\mathbf{3 6}$. This last product showed extra signals in the ${ }^{13} \mathrm{C}$ NMR spectrum due to amide rotamers (Supplementary Materials). 


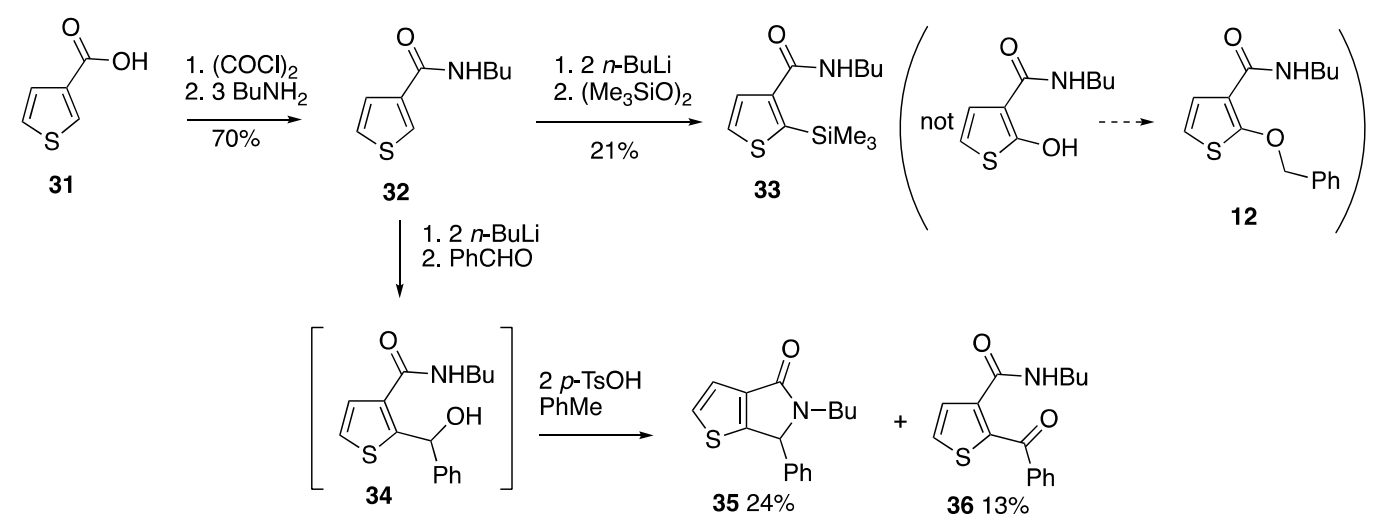

Scheme 8. Formation and cyclisation of secondary alcohol 34.

\subsection{Synthesis of 4-Benzyloxy-3-thienyl Systems $\mathbf{1 3}$ and $\mathbf{1 4}$}

Synthesis of the required compounds in this series was more challenging since suitably substituted thiophene starting materials are not commercially available. Instead, we had to resort to a ring-synthesis of a thiophene with the desired functionality in place. This started from the sulfide-containing diester 37 prepared by conjugate addition of methyl thioglycolate to methyl acrylate [12], which underwent base-induced ring closure [13] to give compound 38 in low yield (Scheme 9). Aromatisation of this was achieved using sulfuryl chloride [14] to give the thiophene ester 39. Conversion of this into the required benzyl ether $\mathbf{4 1}$ proved to be more difficult than expected. Simple alkylation using benzyl bromide and either potassium carbonate or sodium hydride resulted in polymerisation and reaction with phenyldiazomethane [15] also failed.

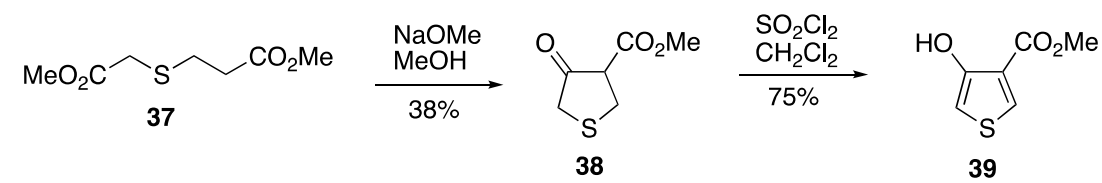<smiles>CC1(C)COC(c2cscc2OCc2ccccc2)=N1</smiles>

13

$$
87 \% \uparrow \mathrm{SOCl}_{2}
$$<smiles>CC(C)(CO)NC(=O)c1cscc1OCc1ccccc1</smiles>

43

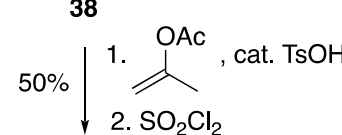
$27 \% \mid \begin{aligned} & \mathrm{PhCH}_{2} \mathrm{Br} \\ & 1.5 \mathrm{Ag}_{2} \mathrm{O}\end{aligned}$<smiles>COC(C)=O</smiles>

$\mathrm{Ph}$<smiles>CC(=O)c1cscc1O</smiles>

40
41

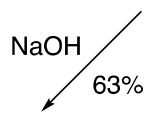

1. $\mathrm{SOCl}_{2}$

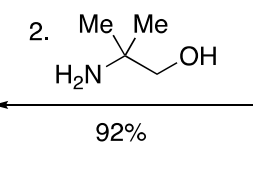<smiles>O=C(O)c1cscc1OCc1ccccc1</smiles>

42

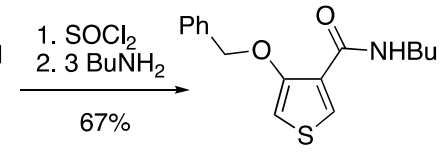

14

Scheme 9. Synthesis of 4-benyloxy-3-thienyl compounds 13 and 14.

Following a literature report that reaction of the 4-acetoxy compound 40 with ethanol and sulfuric acid gave the 4-ethoxy compound [15], this compound was prepared by reaction of $\mathbf{3 8}$ with isopropenyl acetate followed by sulfuryl chloride, but the treatment of this with benzyl alcohol and sulfuric acid again resulted in polymerisation. Access to 41 was finally achieved, albeit in low yield, by resorting to treatment with benzyl bromide in the presence of silver oxide in a process reminiscent of the Purdie-Irvine method for methylation of sugars developed in St Andrews over 100 years ago [16]. With the key intermediate $\mathbf{4 1}$ in hand, the remaining synthetic steps proceeded without incident: hydrolysis gave the acid $\mathbf{4 2}$ which was converted into its acid chloride and then reacted 
either with 2-amino-2-methylpropan-1-ol to give amide 43 which was cyclised with thionyl chloride to oxazoline 13 , or with butylamine to directly afford the amide 14 .

\subsection{Reaction of 4-Benzyloxy-3-thienyl Systems $\mathbf{1 3}$ and $\mathbf{1 4}$ with Base}

Treatment of oxazoline 13 with 3.3 equiv. of Schlosser's base gave largely unreacted starting material, however, increasing this to 4.4 equiv. did give a reaction and after chromatographic purification, the 4-benzoyloxy-3-thienyl amide 45 was isolated in moderate yield (Scheme 10). This is evidently formed by air oxidation of the expected cyclisation product, the 3-aminothieno[3,4-b]furan 44 . As shown in our previous work [1], such ring-fused 3-aminofuran products are susceptible to oxidative ring-cleavage.

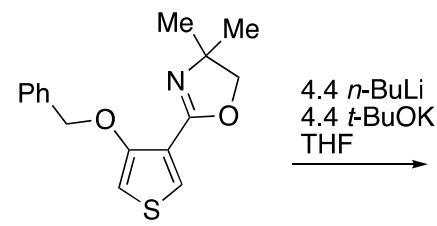

13<smiles>CC(C)(CO)Nc1c(-c2ccccc2)oc2cscc12</smiles>

44

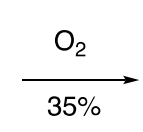<smiles>CC(C)(CO)NC(=O)c1cscc1OC(=O)c1ccccc1</smiles>

45

Scheme 10. Base-induced cyclisation and oxidative ring opening of 13 .

The reaction of the corresponding $\mathrm{N}$-butyl amide $\mathbf{1 4}$ with $n$-BuLi under the conditions required for Wittig rearrangement gave largely unreacted starting material and the only new products isolated in low yield after chromatographic purification (Scheme 11) were the 2,3,4-trisubstituted thiophene 46 together with the debenzylated compound $\mathbf{4 7}$ which was found to exist in solution as a mixture with the thiophen-3(2H)-one tautomer 47 a (see Section 3). It seems likely that the products have resulted from the intermolecular reaction between two carbanions derived from $\mathbf{1 4}$ but in view of their very low yield this process was not investigated further. Products 45, 46 and 47 which were isolated in low amounts following one or two stages of chromatography were found to decompose upon attempted further purification.<smiles>CCCCCNC(=O)c1cscc1OCc1ccccc1</smiles>

14

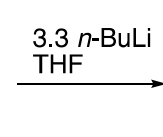

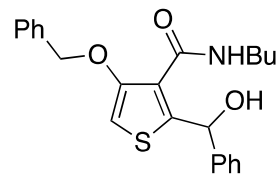

$464 \%$

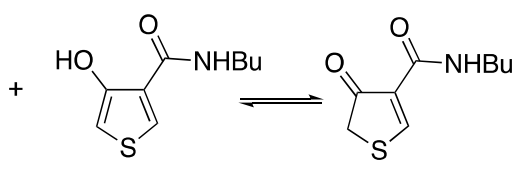

$478 \%$
$47 a$

Scheme 11. Reaction of amide 14 with strong base.

To summarise the reactivity of the isomeric systems, oxazoline $\mathbf{1 1}$ underwent exclusive Wittig rearrangement and oxazoline $\mathbf{1 3}$ gave products derived from cyclisation, while for $\mathbf{9}$ Wittig rearrangement was observed as a minor process with the major product derived from cyclisation. The $\mathrm{N}$-butyl amides gave a less complete picture with $\mathbf{1 0}$ undergoing exclusive Wittig rearrangement in high yield, 12 not being available for investigation (although its expected Wittig rearrangement product was obtained by other means), and $\mathbf{1 4}$ remaining largely unreacted under the conditions. In the case of the three isomeric oxazolines, each compound was obtained as good quality crystals suitable for X-ray diffraction and so it was decided to determine their molecular structures to examine whether there might be a direct link between the distance between the benzyloxy and oxazoline groups and the observed reactivity. All three compounds gave structures with the monoclinic $\mathrm{P} 2_{1} / \mathrm{c}$ space group and these are shown in a similar orientation in Figure 3.

For the intramolecular cyclisation to compete with Wittig rearrangement, the key distance is that between benzyloxy carbanionic carbon and C-2 of the oxazoline. Since the benzyloxy groups have rotated to place this carbon pointing away from the oxazoline in each case, the benzyloxy oxygen is taken as a reference point and it can be seen that the molecular geometry correlates well with the observed reactivity. Thus, for 11, the benzyloxy group is too far away (3.046(1) $\AA$ ) for cyclisation and we observe exclusively 
a Wittig rearrangement, for 13 the benzyloxy group is much closer $(2.945(1) \AA)$ and only products derived from cyclisation are observed, while in $\mathbf{9}$ we have an intermediate situation (3.006(3) $\AA$ ) and mainly cyclisation-derived products are observed but with a little Wittig rearrangement.

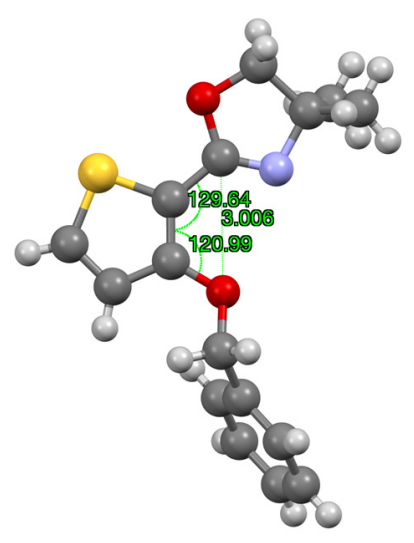

9

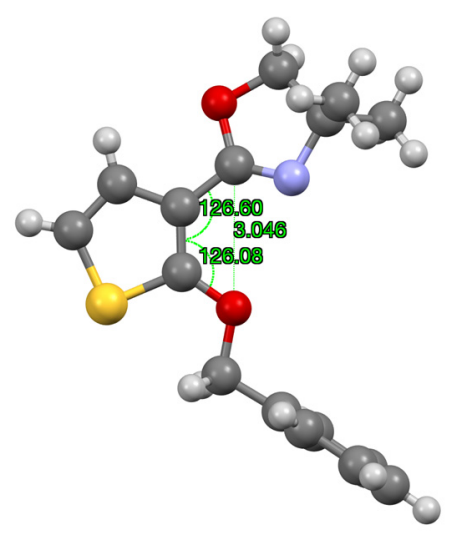

11

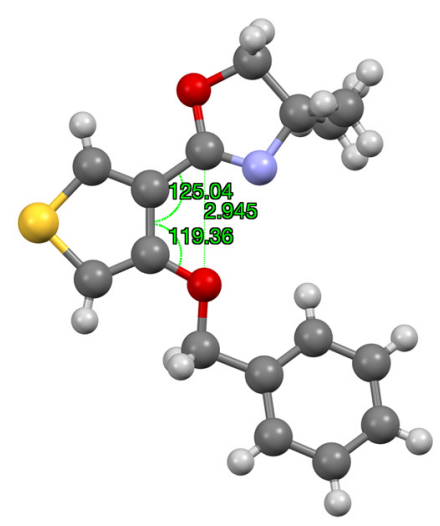

13

Figure 3. Molecular structures of $\mathbf{9 , 1 1}$ and $\mathbf{1 3}$ showing angles $\left(^{\circ}\right)$ and benzyloxy $\mathrm{O}$ to oxazoline $\mathrm{C}(2)$ distance $(\AA)$.

\section{Experimental}

\subsection{General Experimental Details}

NMR spectra were recorded on solutions in $\mathrm{CDCl}_{3}$ unless otherwise stated using Bruker instruments and chemical shifts are given in ppm to high frequency from $\mathrm{Me}_{4} \mathrm{Si}$ with coupling constants $J$ in $\mathrm{Hz}$. IR spectra were recorded using the ATR technique on a Shimadzu IRAffinity $1 S$ instrument. The ionisation method used for high-resolution mass spectra is noted in each case. Column chromatography was carried out using silica gel of 40-63 mm particle size and preparative TLC was carried out using $1.0 \mathrm{~mm}$ layers of Merck alumina $60 \mathrm{G}$ containing $0.5 \%$ Woelm fluorescent green indicator on glass plates. Melting points were recorded on a Gallenkamp 50W melting point apparatus or a Reichert hot-stage microscope.

\subsection{Preparation and Reactions of 3-Benzyloxy-2-thienyl Systems}

\subsubsection{Methyl 3-(Benzyloxy)thiophene-2-carboxylate $\mathbf{1 6}$}

A literature procedure [17] was modified as follows: benzyl bromide $\left(11.9 \mathrm{~cm}^{3}, 17.11 \mathrm{~g}\right.$, $0.100 \mathrm{~mol}$ ) was added to a stirred mixture of methyl 3-hydroxythiophene-2-carboxylate $15(15.85 \mathrm{~g}, 0.100 \mathrm{~mol})$ and potassium carbonate $(27.60 \mathrm{~g}, 0.200 \mathrm{~mol})$ in acetone $\left(50 \mathrm{~cm}^{3}\right)$ and the reaction mixture was heated at reflux for $18 \mathrm{~h}$. After cooling to $\mathrm{rt}$, the inorganic salts were removed by filtration and the filtrate was concentrated in vacuo. The residue was dissolved in $\mathrm{CH}_{2} \mathrm{Cl}_{2}\left(150 \mathrm{~cm}^{3}\right)$ and washed with water $\left(100 \mathrm{~cm}^{3}\right)$ before being dried and evaporated. The crude residue was recrystallised (aq. $\mathrm{MeOH})$ to give $\mathbf{1 6}(18.94 \mathrm{~g}, 76 \%)$ as pale yellow crystals; $\mathrm{mp} 69-72{ }^{\circ} \mathrm{C}$; (lit. [17] $\left.66-67^{\circ} \mathrm{C}\right) ; \delta_{\mathrm{H}}(500 \mathrm{MHz}) 7.46-7.44(2 \mathrm{H}, \mathrm{m}$, $\mathrm{Ph})$, 7.39-7.35 (2H, m, Ph), $7.35(1 \mathrm{H}, \mathrm{d}, J$ 5.5, 5-H), 7.32-7.29 (1H, m, Ph), $6.82(1 \mathrm{H}, \mathrm{d}, J$ 5.5, 4-H), $5.24\left(2 \mathrm{H}, \mathrm{s}, \mathrm{CH}_{2}\right)$ and $3.85\left(3 \mathrm{H}, \mathrm{s}, \mathrm{CH}_{3}\right) ; \delta_{\mathrm{C}}(125 \mathrm{MHz}) 162.1(\mathrm{C}), 160.8(\mathrm{C}), 136.4(\mathrm{C})$, $130.4(\mathrm{CH}), 128.6(2 \mathrm{CH}), 127.9(\mathrm{CH}), 126.8(2 \mathrm{CH}), 117.5(\mathrm{CH}), 110.4(\mathrm{C}), 73.2\left(\mathrm{CH}_{2}\right)$ and 51.6 $\left(\mathrm{CH}_{3}\right)$. The ${ }^{1} \mathrm{H}$ NMR spectral data were in accordance with those previously reported [17]. ${ }^{13} \mathrm{C}$ NMR data are reported for the first time.

\subsubsection{3-(Benzyloxy)thiophene-2-carboxylic Acid 17}

Following a literature procedure [17], a mixture of methyl 3-(benzyloxy)thiophene2-carboxylate 16 (18.40 g, $74.1 \mathrm{mmol})$ and sodium hydroxide $(5.99 \mathrm{~g}, 0.150 \mathrm{~mol})$ in water $\left(150 \mathrm{~cm}^{3}\right)$ was heated at reflux for $2.5 \mathrm{~h}$. After cooling to $\mathrm{rt}$, the aqueous layer was washed with $\mathrm{CH}_{2} \mathrm{Cl}_{2}\left(2 \times 50 \mathrm{~cm}^{3}\right)$ before being acidified to $\mathrm{pH} 1$ by the addition of $2 \mathrm{M} \mathrm{HCl}$. The resultant suspension was extracted with $\mathrm{CH}_{2} \mathrm{Cl}_{2}\left(2 \times 100 \mathrm{~cm}^{3}\right)$ and the combined organic 
layers were dried and evaporated. The crude residue was recrystallised (aq. $\mathrm{MeOH}$ ) to give $17(15.07 \mathrm{~g}, 87 \%)$ as tan-coloured crystals; $\mathrm{mp} 122-125^{\circ} \mathrm{C}$; (lit. [17] $\left.125-126^{\circ} \mathrm{C}\right) ; \delta_{\mathrm{H}}$ $\left(400 \mathrm{MHz}, \mathrm{CD}_{3} \mathrm{SOCD}_{3}\right) 12.49\left(1 \mathrm{H}\right.$, br s, $\left.\mathrm{CO}_{2} \mathrm{H}\right), 7.74(1 \mathrm{H}, \mathrm{d}, J$ 5.6, 5-H), 7.48-7.45 $(2 \mathrm{H}, \mathrm{m}$, $\mathrm{Ph}), 7.41-7.37(2 \mathrm{H}, \mathrm{m}, \mathrm{Ph}), 7.35-7.30(1 \mathrm{H}, \mathrm{m}, \mathrm{Ph}), 7.14(1 \mathrm{H}, \mathrm{d}, J 5.6,4-\mathrm{H})$ and $5.25(2 \mathrm{H}, \mathrm{s}$, $\left.\mathrm{CH}_{2}\right) ; \delta_{\mathrm{C}}\left(100 \mathrm{MHz}, \mathrm{CD}_{3} \mathrm{SOCD}_{3}\right) 162.4(\mathrm{C}), 160.1(\mathrm{C}), 136.8(\mathrm{C}), 131.2(\mathrm{CH}), 128.4(2 \mathrm{CH})$, 127.9 (CH), $127.3(2 \mathrm{CH}), 118.5(\mathrm{Ar} \mathrm{CH}), 110.5(\mathrm{C})$ and $72.4\left(\mathrm{CH}_{2}\right)$. The ${ }^{1} \mathrm{H}$ NMR spectral data were in accordance with those previously reported [17]. ${ }^{13} \mathrm{C}$ NMR data are reported for the first time.

\subsubsection{3-(Benzyloxy)- $N$-(1-hydroxy-2-methylpropan-2-yl)thiophene-2-carboxamide $\mathbf{1 8}$}

Oxalyl chloride $\left(3.0 \mathrm{~cm}^{3}, 4.50 \mathrm{~g}, 35.5 \mathrm{mmol}\right)$ was added to a suspension of 3-(benzyloxy)thiophene-2-carboxylic acid $17(4.00 \mathrm{~g}, 17.1 \mathrm{mmol})$ and in $\mathrm{Et}_{2} \mathrm{O}\left(25 \mathrm{~cm}^{3}\right)$ and the mixture was stirred for $18 \mathrm{~h}$. Evaporation gave 3-(benzyloxy)thiophene-2-carbonyl chloride as a brown oil which was used without further purification.

A solution of 3-(benzyloxy)thiophene-2-carbonyl chloride (assuming $17.1 \mathrm{mmol}$ ) in $\mathrm{CH}_{2} \mathrm{Cl}_{2}\left(40 \mathrm{~cm}^{3}\right)$ was added dropwise to a solution of 2-amino-2-methylpropan-1-ol (3.10 g, $34.8 \mathrm{mmol})$ in $\mathrm{CH}_{2} \mathrm{Cl}_{2}\left(40 \mathrm{~cm}^{3}\right)$ stirred at $0{ }^{\circ} \mathrm{C}$. After the addition, the mixture was allowed to warm to $\mathrm{rt}$ and stirred for $18 \mathrm{~h}$ before being poured into water. The organic layer was separated and the aqueous layer was extracted with $\mathrm{CH}_{2} \mathrm{Cl}_{2}\left(2 \times 20 \mathrm{~cm}^{3}\right)$. The combined organic layers were washed successively with $2 \mathrm{M} \mathrm{HCl}, 2 \mathrm{M} \mathrm{NaOH}$ and water before being dried and evaporated to give $\mathbf{1 8}(5.14 \mathrm{~g}, 99 \%)$ as a pale yellow solid which was used without further purification; $\mathrm{mp} 112-115^{\circ} \mathrm{C} ; v_{\max } / \mathrm{cm}^{-1} 3358,3065,2968,1626,1531,1425,1240$, 1057, 777, 704 and 600; $\delta_{\mathrm{H}}(500 \mathrm{MHz}) 7.43-7.40(6 \mathrm{H}, \mathrm{m}, \mathrm{NH}$ and Ph), $7.41(1 \mathrm{H}, \mathrm{d}, J 5.5,5-\mathrm{H})$, $6.93(1 \mathrm{H}, \mathrm{d}, J 5.5,4-\mathrm{H}), 5.18\left(2 \mathrm{H}, \mathrm{s}, \mathrm{OCH}_{2} \mathrm{Ph}\right), 3.58\left(2 \mathrm{H}, \mathrm{s}, \mathrm{CH}_{2} \mathrm{OH}\right)$ and $1.19\left(6 \mathrm{H}, \mathrm{s}, \mathrm{CH}_{3}\right) ; \delta_{\mathrm{C}}$ $(125 \mathrm{MHz}) 162.5(\mathrm{C}), 155.3(\mathrm{C}), 135.2(\mathrm{C}), 129.2(\mathrm{CH}), 129.0(\mathrm{CH}), 128.8(2 \mathrm{CH}), 128.0(2 \mathrm{CH})$, 117.6 (C), $116.2(\mathrm{CH}), 74.1\left(\mathrm{CH}_{2}\right), 70.9\left(\mathrm{CH}_{2}\right), 56.3\left(\mathrm{CMe}_{2}\right)$ and $24.8\left(2 \mathrm{CH}_{3}\right)$; HRMS $\left(\mathrm{NSI}^{+}\right)$: found 306.1150. $\mathrm{C}_{16} \mathrm{H}_{20} \mathrm{NO}_{3} \mathrm{~S}(\mathrm{M}+\mathrm{H})$ requires 306.1158 .

\subsubsection{2-(3-(Benzyloxy)thiophen-2-yl)-4,4-dimethyl-4,5-dihydrooxazole 9}

Thionyl chloride $\left(1.4 \mathrm{~cm}^{3}, 2.28 \mathrm{~g}, 19.2 \mathrm{mmol}\right)$ was added to a solution of 3-(benzyloxy)$\mathrm{N}$-(1-hydroxy-2-methylpropan-2-yl)thiophene-2-carboxamide 18 (4.71 g, $15.4 \mathrm{mmol}$ ) in $\mathrm{CH}_{2} \mathrm{Cl}_{2}\left(50 \mathrm{~cm}^{3}\right)$ and the mixture was stirred at room temperature for $18 \mathrm{~h}$. The mixture was washed with $2 \mathrm{M} \mathrm{NaOH}$ and water before being dried and evaporated to give $9(4.01 \mathrm{~g}$, $90 \%$ ) as a pale brown oil which solidified on standing as a tan-coloured solid; mp $65-68^{\circ} \mathrm{C}$; $v_{\max } / \mathrm{cm}^{-1} 3080,2965,1632,1545,1260,1231,1200,1069,1026,766$ and $745 ; \delta_{\mathrm{H}}(500 \mathrm{MHz})$ 7.45-7.42 (2H, m, Ph), 7.37-7.33 (2H, m, Ph), 7.31-7.27 (1H, m, Ph), 7.24 (1H, d, J 5.5, 5-H), $6.78(1 \mathrm{H}, \mathrm{d}, J 5.5,4-\mathrm{H}), 5.24\left(2 \mathrm{H}, \mathrm{s}, \mathrm{OCH}_{2} \mathrm{Ph}\right), 4.09\left(2 \mathrm{H}, \mathrm{s}, \mathrm{OCH}_{2}\right)$ and $1.38\left(6 \mathrm{H}, \mathrm{s}, \mathrm{CH}_{3}\right)$ $\delta_{\mathrm{C}}(125 \mathrm{MHz}) 157.6(\mathrm{C}), 157.3(\mathrm{C}), 136.8(\mathrm{C}), 128.4(2 \mathrm{CH}), 127.8(2 \mathrm{CH}), 126.9(2 \mathrm{CH}), 118.1$ $(\mathrm{CH}), 108.9(\mathrm{C}), 79.2\left(\mathrm{CH}_{2}\right), 73.4\left(\mathrm{CH}_{2}\right), 67.1\left(\mathrm{CMe}_{2}\right)$ and $28.3\left(2 \mathrm{CH}_{3}\right)$; HRMS $\left(\mathrm{ESI}^{+}\right)$: found 288.1047. $\mathrm{C}_{16} \mathrm{H}_{18} \mathrm{NO}_{2} \mathrm{~S}(\mathrm{M}+\mathrm{H})$ requires 288.1053.

\subsubsection{3-(Benzyloxy)- $N$-butylthiophene-2-carboxamide 10}

Thionyl chloride $\left(2.5 \mathrm{~cm}^{3}, 4.08 \mathrm{~g}, 34.3 \mathrm{mmol}\right)$ was added to a suspension of 3(benzyloxy)thiophene-2-carboxylic acid $17(4.00 \mathrm{~g}, 17.1 \mathrm{mmol})$ in toluene $\left(30 \mathrm{~cm}^{3}\right)$ and the mixture was heated under reflux for $3 \mathrm{~h}$. After cooling to room temperature, the mixture was evaporated to give 3-(benzyloxy)thiophene-2-carbonyl chloride as a brown oil which was used without further purification.

A solution of 3-(benzyloxy)thiophene-2-carbonyl chloride (assuming $17.1 \mathrm{mmol}$ ) in toluene $\left(30 \mathrm{~cm}^{3}\right)$ was added dropwise to a solution of $n$-butylamine $\left(5.1 \mathrm{~cm}^{3}, 3.77 \mathrm{~g}\right.$, $51.6 \mathrm{mmol})$ in toluene $\left(10 \mathrm{~cm}^{3}\right)$ stirred at $0{ }^{\circ} \mathrm{C}$. Once the addition was complete, the reaction mixture was allowed to warm to room temperature over $1 \mathrm{~h}$ before being poured into water. The organic layer was separated and washed with $2 \mathrm{M} \mathrm{NaOH}$ and brine, dried and evaporated to give, after purification by column chromatography $\left(\mathrm{SiO}_{2}, \mathrm{Et}_{2} \mathrm{O} /\right.$ hexane 7:3), at $R_{\mathrm{f}} 0.65,10(4.49 \mathrm{~g}, 91 \%)$ as an orange oil; $v_{\max } / \mathrm{cm}^{-1} 3364,2961,1628,1558,1435,1364$, 
1310, 1074, 976, 773 and 606; $\delta_{\mathrm{H}}(500 \mathrm{MHz}) 7.43-7.38(5 \mathrm{H}, \mathrm{m}, \mathrm{Ph}), 7.36(1 \mathrm{H}, \mathrm{d}, J$ 5.5, 5-H), $7.19\left(1 \mathrm{H}\right.$, br s, NH), $6.89(1 \mathrm{H}, \mathrm{d}, J 5.5,4-\mathrm{H}), 5.19\left(2 \mathrm{H}, \mathrm{s}, \mathrm{OCH}_{2}\right), 3.36\left(2 \mathrm{H}, \mathrm{td}, J 7.0,5.5, \mathrm{NCH}_{2}\right)$, 1.47-1.41 (2H, m, $\left.\mathrm{NCH}_{2} \mathrm{CH}_{2}\right), 1.28-1.20\left(2 \mathrm{H}, \mathrm{m}, \mathrm{CH}_{2} \mathrm{CH}_{3}\right)$ and $0.85\left(3 \mathrm{H}, \mathrm{t}, J 7.5, \mathrm{CH}_{3}\right) ; \delta_{\mathrm{C}}$ $(125 \mathrm{MHz}) 161.7(\mathrm{C}), 154.9(\mathrm{C}), 135.6(\mathrm{C}), 128.84(2 \mathrm{CH}), 128.76(\mathrm{CH}), 128.5(\mathrm{CH}), 127.7(2 \mathrm{CH})$, $118.1(\mathrm{C}), 116.2(\mathrm{CH}), 73.9\left(\mathrm{OCH}_{2}\right), 38.9\left(\mathrm{NCH}_{2}\right), 31.5\left(\mathrm{CH}_{2}\right), 20.0\left(\mathrm{CH}_{2}\right)$ and $13.7\left(\mathrm{CH}_{3}\right)$; HRMS $\left(\mathrm{ESI}^{+}\right)$: found 312.1017. $\mathrm{C}_{16} \mathrm{H}_{19} \mathrm{NaNO}_{2} \mathrm{~S}(\mathrm{M}+\mathrm{Na})$ requires 312.1029.

3.2.6. (2-(4,4-Dimethyl-4,5-dihydrooxazol-2-yl)thiophen-3-yl)(phenyl)methanol 19 and (E)-2-(2-Hydroxy-5,5-dimethyl-2-phenylmorpholin-3-ylidene)thiophen-3(2H)-one 20

Under a nitrogen atmosphere, $n$-butyllithium $\left(2.5 \mathrm{M}\right.$ in hexanes, $\left.0.66 \mathrm{~cm}^{3}, 1.65 \mathrm{mmol}\right)$ was added to a stirred mixture of 2-(3-(benzyloxy)thiophen-2-yl)-4,4-dimethyl-4,5dihydrooxazole $9(0.1440 \mathrm{~g}, 0.50 \mathrm{mmol})$ and potassium tert-butoxide $(0.1850 \mathrm{~g}, 1.65 \mathrm{mmol})$ in dry THF $\left(5 \mathrm{~cm}^{3}\right)$. The mixture was stirred at $\mathrm{rt}$ for $2 \mathrm{~h}$ before being quenched by the addition of saturated aq. $\mathrm{NH}_{4} \mathrm{Cl}$ and extracted with $\mathrm{Et}_{2} \mathrm{O}\left(3 \times 10 \mathrm{~cm}^{3}\right)$. The combined extracts were dried and evaporated to give, after purification by preparative TLC $\left(\mathrm{Al}_{2} \mathrm{O}_{3}\right.$, $\mathrm{Et}_{2} \mathrm{O} /$ hexane $\left.7: 3\right)$, at $\mathrm{R}_{\mathrm{f}} 0.65,19(12 \mathrm{mg}, 8 \%)$ as an orange oil; $\delta_{\mathrm{H}}(400 \mathrm{MHz}) 7.42-7.38(2 \mathrm{H}$, $\mathrm{m}, \mathrm{Ph}), 7.34-7.30$ (3H, m, ArH and Ph), 7.28-7.23 (1H, m, Ph), $6.71(1 \mathrm{H}, \mathrm{d}, J$ 5.2, ArH), 6.02 $(1 \mathrm{H}, \mathrm{s}, \mathrm{CHOH}), 4.11$ and $4.09\left(2 \mathrm{H}, \mathrm{AB}\right.$ pattern, $\left.J 8.2, \mathrm{CH}_{2}\right), 1.40\left(3 \mathrm{H}, \mathrm{s}, \mathrm{CH}_{3}\right)$ and $1.27(3 \mathrm{H}$, $\left.\mathrm{s}, \mathrm{CH}_{3}\right) ; \delta_{\mathrm{C}}(125 \mathrm{MHz}) 158.6(\mathrm{C}), 150.4(\mathrm{C}), 142.8(\mathrm{C}), 130.1(\mathrm{CH}), 128.2(\mathrm{CH}), 128.0(2 \mathrm{CH})$, $127.1(\mathrm{CH}), 126.5(2 \mathrm{CH}), 124.7(\mathrm{C}), 79.5\left(\mathrm{CH}_{2}\right), 70.9(\mathrm{CHOH}), 68.1\left(\mathrm{CMe}_{2}\right), 28.3\left(\mathrm{CH}_{3}\right)$ and $28.1\left(\mathrm{CH}_{3}\right)$. The ${ }^{1} \mathrm{H}$ NMR spectral data were consistent with those previously reported [18]. ${ }^{13} \mathrm{C} \mathrm{NMR}$ data are reported for the first time.

This was followed by a second fraction, at $R_{\mathrm{f}} 0.15$, to give $20(64.5 \mathrm{mg}, 42 \%)$ in slightly impure form as brown crystals; $\mathrm{mp} 103-105^{\circ} \mathrm{C} ; v_{\max } / \mathrm{cm}^{-1} 1582,1537,1449,1317,1260$, $1221,1067,768,698$ and $669 ; \delta_{\mathrm{H}}\left(400 \mathrm{MHz}, \mathrm{CD}_{3} \mathrm{COCD}_{3}\right) 7.65-7.62(2 \mathrm{H}, \mathrm{m}, \mathrm{Ph}), 7.52(1 \mathrm{H}, \mathrm{d}, J$ 5.6, 5-H), 7.40-7.35 (3H, m, Ph), $6.32(1 \mathrm{H}, \mathrm{d}, J 5.6,4-\mathrm{H}), 4.12$ and 3.69 (2H, AB pattern, J 11.6, $\left.\mathrm{CH}_{2}\right), 3.06(2 \mathrm{H}$, br s, $\mathrm{OH}$ and $\mathrm{NH}), 1.53\left(3 \mathrm{H}, \mathrm{s}, \mathrm{CH}_{3}\right)$ and $1.39\left(3 \mathrm{H}, \mathrm{s}, \mathrm{CH}_{3}\right) ; \delta_{\mathrm{C}}(125 \mathrm{MHz}$, $\left.\left.\mathrm{CD}_{3} \mathrm{COCD}_{3}\right) 182.1(\mathrm{C}=\mathrm{O}), 162.7(\mathrm{C})\right), 141.5(\mathrm{C}), 138.5(\mathrm{CH}), 129.5(\mathrm{CH}), 128.6(2 \mathrm{CH}), 127.6$ $(2 \mathrm{CH}), 122.1(\mathrm{CH}), 103.5(\mathrm{C}), 95.0(\mathrm{C}), 68.3\left(\mathrm{CH}_{2}\right), 51.4\left(\mathrm{CMe}_{2}\right), 26.8\left(\mathrm{CH}_{3}\right)$ and $26.5\left(\mathrm{CH}_{3}\right)$; HRMS $\left(\mathrm{NSI}^{+}\right)$: found 304.1004. $\mathrm{C}_{16} \mathrm{H}_{18} \mathrm{NO}_{3} \mathrm{~S}(\mathrm{M}+\mathrm{H})$ requires 304.1002.

3.2.7. N-Butyl-3-(hydroxy(phenyl)methyl)thiophene-2-carboxamide 25 and

5-Butyl-4-phenyl-4,5-dihydro-6H-thieno[2,3-c]pyrrol-6-one 26

Under a nitrogen atmosphere, $n$-butyllithium $\left(2.5 \mathrm{M}\right.$ in hexanes, $\left.6.6 \mathrm{~cm}^{3}, 16.5 \mathrm{mmol}\right)$ was added dropwise to a stirred solution of 3-(benzyloxy)- $N$-butylthiophene-2-carboxamide $10(1.45 \mathrm{~g}, 5.01 \mathrm{mmol})$ in dry THF $\left(50 \mathrm{~cm}^{3}\right)$. After stirring at room temperature for $2 \mathrm{~h}$, the reaction mixture was quenched by the addition of saturated aq. $\mathrm{NH}_{4} \mathrm{Cl}$ and extracted with $\mathrm{Et}_{2} \mathrm{O}\left(3 \times 30 \mathrm{~cm}^{3}\right)$. The combined organic extracts were washed with $\mathrm{NaOH}$ and water before being dried and evaporated to give $\mathbf{2 5}$ as a pale brown oil which was used without further purification; $v_{\max } / \mathrm{cm}^{-1} 3256,3086,2957,2930,1612,1545,1450,1302,1026,698$ and $669 ; \delta_{\mathrm{H}}(400 \mathrm{MHz}) 7.37-7.29(4 \mathrm{H}, \mathrm{m}, \mathrm{Ph}), 7.27-7.23(1 \mathrm{H}, \mathrm{m}, \mathrm{Ph}), 7.21(1 \mathrm{H}, \mathrm{d}, J$ 5.0, 5-H), 6.96 $(1 \mathrm{H}, \mathrm{t}, J 5.6, \mathrm{NH}), 6.71(1 \mathrm{H}, \mathrm{d}, J 5.0,4-\mathrm{H}), 6.02(1 \mathrm{H}, \mathrm{s}, \mathrm{CHOH}), 5.87(1 \mathrm{H}$, br s, OH), $3.30(2 \mathrm{H}$, $\mathrm{td}, J$ 7.2, 5.6, $\left.\mathrm{NCH}_{2}\right), 1.52-1.45\left(2 \mathrm{H}, \mathrm{m}, \mathrm{NCH}_{2} \mathrm{CH}_{2}\right), 1.35-1.26\left(2 \mathrm{H}, \mathrm{m}, \mathrm{CH}_{2} \mathrm{CH}_{3}\right)$ and 0.89 $\left(3 \mathrm{H}, \mathrm{t}, J 7.2, \mathrm{CH}_{3}\right) ; \delta_{\mathrm{C}}(75 \mathrm{MHz}) 163.1(\mathrm{C}=\mathrm{O}), 147.8(\mathrm{C}), 142.3(\mathrm{C}), 133.4(\mathrm{C}), 130.4(\mathrm{CH}), 128.2$ $(2 \mathrm{CH}), 127.3(\mathrm{CH}), 126.7(\mathrm{CH}), 126.2(2 \mathrm{CH}), 70.9(\mathrm{CHOH}), 39.9\left(\mathrm{NCH}_{2}\right), 31.3\left(\mathrm{CH}_{2}\right), 20.0$ $\left(\mathrm{CH}_{2}\right)$ and $13.7\left(\mathrm{CH}_{3}\right)$; HRMS $\left(\mathrm{ESI}^{+}\right)$: found 312.1023. $\mathrm{C}_{16} \mathrm{H}_{19} \mathrm{NaNO}_{2} \mathrm{~S}(\mathrm{M}+\mathrm{Na})$ requires 312.1029.

A mixture of $N$-butyl-3-(hydroxy(phenyl)methyl)thiophene-2-carboxamide 25 (assuming $5.01 \mathrm{mmol})$ and $p$-toluenesulfonic acid monohydrate $(1.90 \mathrm{~g}, 9.99 \mathrm{mmol})$ in toluene $\left(50 \mathrm{~cm}^{3}\right)$ was heated at reflux for $1 \mathrm{~h}$. After cooling to room temperature, the reaction mixture was washed with water $\left(50 \mathrm{~cm}^{3}\right), 2 \mathrm{M} \mathrm{NaOH}\left(50 \mathrm{~cm}^{3}\right)$ and brine $\left(50 \mathrm{~cm}^{3}\right)$ before being dried and evaporated. The crude residue was purified by filtration through a silica plug $\left(\mathrm{Et}_{2} \mathrm{O}\right)$ to give $26(1.26 \mathrm{~g}, 93 \%)$ as a tan-coloured solid; mp 90-93 ${ }^{\circ} \mathrm{C} ; v_{\max } / \mathrm{cm}^{-1} 2955$, 1668, 1441, 1398, 1310, 1069, 781, 743, 698 and 637; $\delta_{\mathrm{H}}(400 \mathrm{MHz}) 7.55(1 \mathrm{H}, \mathrm{d}, J$ 4.8, 5-H), 7.38-7.32 (3H, m, Ph), 7.16-7.13 (2H, m, Ph), 6.79 (1H, d, J 4.8, 4-H), 5.39 (1H, s, CHPh), 3.84 
$(1 \mathrm{H}, \mathrm{dt}, J 14.4,7.8, \mathrm{NCH}), 2.86-2.79(1 \mathrm{H}, \mathrm{m}, \mathrm{NCH}), 1.54-1.46\left(2 \mathrm{H}, \mathrm{m}, \mathrm{NCH}_{2} \mathrm{CH}_{2}\right), 1.34-1.24$ $\left(2 \mathrm{H}, \mathrm{m}, \mathrm{CH}_{2} \mathrm{CH}_{3}\right)$ and $0.88\left(3 \mathrm{H}, \mathrm{t}, \mathrm{J} 7.2, \mathrm{CH}_{3}\right) ; \delta_{\mathrm{C}}(125 \mathrm{MHz}) 164.4(\mathrm{C}=\mathrm{O}), 155.7(\mathrm{C}), 136.0(\mathrm{C})$, $134.8(\mathrm{C}), 134.5(\mathrm{CH}), 129.0(2 \mathrm{CH}), 128.6(\mathrm{CH}), 127.3(2 \mathrm{CH}), 120.7(\mathrm{CH}), 62.9(\mathrm{CHPh}), 40.3$ $\left(\mathrm{NCH}_{2}\right), 30.6\left(\mathrm{CH}_{2}\right), 19.9\left(\mathrm{CH}_{2}\right)$ and $13.7\left(\mathrm{CH}_{3}\right)$; HRMS $\left(\mathrm{NSI}^{+}\right)$: found $272.1103 . \mathrm{C}_{16} \mathrm{H}_{18} \mathrm{NOS}$ $(\mathrm{M}+\mathrm{H})$ requires 272.1104 .

\subsection{Preparation and Reactions of 2-Benzyloxy-3-thienyl Systems}

3.3.1. Attempted Cyclisation of 2-(2-(Benzyloxy)thiophen-3-yl)-4,4-dimethyl-4,5dihydrooxazole $\mathbf{1 1}$

Under a nitrogen atmosphere, $n$-butyllithium $\left(2.5 \mathrm{M}\right.$ in hexanes, $\left.0.66 \mathrm{~cm}^{3}, 1.65 \mathrm{mmol}\right)$ was added to a stirred mixture of 2-(2-(benzyloxy)thiophen-3-yl)-4,4-dimethyl-4,5dihydrooxazole 11 [11] $(0.1437 \mathrm{~g}, 0.50 \mathrm{mmol})$ and potassium tert-butoxide $(0.1875 \mathrm{~g}$, $1.67 \mathrm{mmol})$ in dry THF $\left(5 \mathrm{~cm}^{3}\right)$. The mixture was stirred at $\mathrm{rt}$ for $2 \mathrm{~h}$ before being quenched by the addition of saturated aq. $\mathrm{NH}_{4} \mathrm{Cl}$ and extracted with $\mathrm{Et}_{2} \mathrm{O}\left(3 \times 10 \mathrm{~cm}^{3}\right)$. The combined extracts were dried and evaporated to give, after purification by preparative TLC $\left(\mathrm{Al}_{2} \mathrm{O}_{3}, \mathrm{Et}_{2} \mathrm{O} /\right.$ hexane 1:1), at $\mathrm{R}_{\mathrm{f}}$ 0.50, (3-(4,4-Dimethyl-4,5-dihydrooxazol-2-yl)thiophen-2yl)(phenyl)methanol 30 (96.7 $\mathrm{mg}, 67 \%)$ as an orange oil; $v_{\max } / \mathrm{cm}^{-1} 3177,2965,1636,1535$, 1452, 1288, 1194, 1148, 974 and 698; $\delta_{\mathrm{H}}(500 \mathrm{MHz}) 8.04(1 \mathrm{H}$, br s, OH), $7.49(2 \mathrm{H}, \mathrm{d}, \mathrm{J}$ 7.0, Ph), 7.36-7.28 (4H, m, ArH and Ph), $7.06(1 \mathrm{H}, \mathrm{d}, J$ 5.0, ArH), $6.10(1 \mathrm{H}, \mathrm{s}, \mathrm{CHOH}), 4.09$ and 4.06 $\left(2 \mathrm{H}, \mathrm{AB}\right.$ pattern, $\left.J 6.8, \mathrm{CH}_{2}\right), 1.38\left(3 \mathrm{H}, \mathrm{s}, \mathrm{CH}_{3}\right)$ and $1.28\left(3 \mathrm{H}, \mathrm{s}, \mathrm{CH}_{3}\right) ; \delta_{\mathrm{C}}(125 \mathrm{MHz}) 159.6$ (C), $153.7(\mathrm{C}), 141.8(\mathrm{C}), 128.6(\mathrm{CH}), 127.9(2 \mathrm{CH}), 127.7(\mathrm{CH}), 126.8(2 \mathrm{CH}), 125.5(\mathrm{C}), 123.2$ $(\mathrm{CH}), 79.0\left(\mathrm{CH}_{2}\right), 69.5(\mathrm{CHOH}), 67.3\left(4 \mathrm{ry}, \mathrm{CMe}_{2}\right), 28.5\left(\mathrm{CH}_{3}\right)$ and $28.1\left(\mathrm{CH}_{3}\right)$; $\mathrm{HRMS}\left(\mathrm{NSI}^{+}\right)$: found 288.1052. $\mathrm{C}_{16} \mathrm{H}_{18} \mathrm{NO}_{2} \mathrm{~S}(\mathrm{M}+\mathrm{H})$ requires 288.1053 .

\subsubsection{N-Butylthiophene-3-carboxamide 32}

Oxalyl chloride $\left(2.0 \mathrm{~cm}^{3}, 3.00 \mathrm{~g}, 23.6 \mathrm{mmol}\right)$ was added to a solution of thiophene-3carboxylic acid $31(2.52 \mathrm{~g}, 19.7 \mathrm{mmol})$ in $\mathrm{CH}_{2} \mathrm{Cl}_{2}\left(30 \mathrm{~cm}^{3}\right)$ and the mixture was stirred for $18 \mathrm{~h}$. Evaporation gave thiophene-3-carbonyl chloride as a pale-yellow solid which was used immediately without further purification.

A solution of thiophene-3-carbonyl chloride (assuming $19.7 \mathrm{mmol}$ ) in toluene $\left(30 \mathrm{~cm}^{3}\right)$ was added dropwise to a solution of $n$-butylamine $\left(5.8 \mathrm{~cm}^{3}, 4.29 \mathrm{~g}, 58.7 \mathrm{mmol}\right)$ in toluene $\left(30 \mathrm{~cm}^{3}\right)$ stirred at $0{ }^{\circ} \mathrm{C}$. Once the addition was complete, the reaction mixture was allowed to warm to rt over $1 \mathrm{~h}$ before being poured into water. The organic layer was separated and washed with $2 \mathrm{M} \mathrm{NaOH}$ and brine, dried and evaporated to give, after recrystallisation (EtOAc/hexane), $32(2.54 \mathrm{~g}, 70 \%)$ as colourless crystals; $\mathrm{mp} 66-68^{\circ} \mathrm{C}$; (lit. [19] 53-55 $\left.{ }^{\circ} \mathrm{C}\right)$; $v_{\max } / \mathrm{cm}^{-1} 3253,3085,2921,1617,1555,1301,1220,1127,881,831,741$ and $707 ; \delta_{\mathrm{H}}(500 \mathrm{MHz})$ 7.84 (1H, dd, J 3.0, 1.5, ArH), 7.37 (1H, dd, J 5.0, 1.5, ArH), 7.33 (1H, dd, J 5.0, 3.0, ArH), 6.02 $\left(1 \mathrm{H}\right.$, br s, NH) $3.43\left(2 \mathrm{H}, \mathrm{td}, J 7.0,6.0, \mathrm{NCH}_{2}\right), 1.62-1.56\left(2 \mathrm{H}, \mathrm{m}, \mathrm{NCH}_{2} \mathrm{CH}_{2}\right), 1.44-1.37(2 \mathrm{H}$, $\left.\mathrm{m}, \mathrm{CH}_{2} \mathrm{CH}_{3}\right)$ and $0.95\left(3 \mathrm{H}, \mathrm{t}, J 7.5, \mathrm{CH}_{3}\right)$. The ${ }^{1} \mathrm{H}$ NMR spectral data were in accordance with those previously reported [19]. IR data are reported for the first time.

\subsubsection{N-Butyl-2-(trimethylsilyl)thiophene-3-carboxamide 33}

Under a nitrogen atmosphere, $n$-butyllithium $\left(2.5 \mathrm{M}\right.$ in hexane, $\left.5.2 \mathrm{~cm}^{3}, 13.0 \mathrm{mmol}\right)$ was added dropwise to a stirred $-78{ }^{\circ} \mathrm{C}$ solution of $N$-butylthiophene-3-carboxamide 32 $(1.10 \mathrm{~g}, 6.00 \mathrm{mmol})$ in dry THF $\left(30 \mathrm{~cm}^{3}\right)$. After stirring at $-78{ }^{\circ} \mathrm{C}$ for $5 \mathrm{~min}$, the reaction mixture was allowed to warm to $\mathrm{rt}$ for $1 \mathrm{~h}$, before being cooled to $-78{ }^{\circ} \mathrm{C}$ and treated with bis(trimethylsilyl) peroxide $(1.28 \mathrm{~g}, 7.18 \mathrm{mmol})$. The reaction mixture was allowed to warm to rt over $18 \mathrm{~h}$ before being poured into sat. aq. $\mathrm{NH}_{4} \mathrm{Cl}\left(100 \mathrm{~cm}^{3}\right)$ and extracted with $\mathrm{Et}_{2} \mathrm{O}\left(3 \times 50 \mathrm{~cm}^{3}\right)$. The combined organic extracts were dried and evaporated and the crude residue was purified by column chromatography $\left(\mathrm{SiO}_{2}, \mathrm{Et}_{2} \mathrm{O} /\right.$ hexane 3:2) to give, at $R_{\mathrm{f}} 0.90,33(0.32 \mathrm{~g}, 21 \%)$ as tan-coloured crystals; $\mathrm{mp} 86-89^{\circ} \mathrm{C} ; v_{\mathrm{max}} / \mathrm{cm}^{-1} 3285$, $2957,1620,1558,1402,1296,1240,1005,833,746,704$ and $604 ; \delta_{\mathrm{H}}(500 \mathrm{MHz}) 7.50(1 \mathrm{H}, \mathrm{d}$, J 5.0, ArH), $7.29(1 \mathrm{H}, \mathrm{d}, J$ 5.0, $\mathrm{ArH}), 5.94(1 \mathrm{H}, \mathrm{br} \mathrm{s}, \mathrm{NH}), 3.41\left(2 \mathrm{H}, \mathrm{td}, J\right.$ 7.0, 6.0, $\left.\mathrm{NCH}_{2}\right)$, 1.61-1.55 (2H, m, $\left.\mathrm{NCH}_{2} \mathrm{CH}_{2}\right), 1.43-1.36\left(2 \mathrm{H}, \mathrm{m}, \mathrm{CH}_{2} \mathrm{CH}_{3}\right), 0.94\left(3 \mathrm{H}, \mathrm{t}, J \mathrm{~J} .5, \mathrm{CH}_{2} \mathrm{CH}_{3}\right)$ and 
$0.39\left(9 \mathrm{H}, \mathrm{s}, \mathrm{SiMe}_{3}\right) ; \delta_{\mathrm{C}}(125 \mathrm{MHz}) 164.6(\mathrm{C}=\mathrm{O}), 145.7(\mathrm{C}), 143.0(\mathrm{C}), 130.2(\mathrm{CH}), 126.9(\mathrm{CH})$, $39.6\left(\mathrm{NCH}_{2}\right), 31.7\left(\mathrm{CH}_{2}\right), 20.1\left(\mathrm{CH}_{2}\right), 13.8\left(\mathrm{CH}_{3}\right)$ and $0.0\left(\mathrm{SiMe}_{3}\right) ; \mathrm{HRMS}\left(\mathrm{NSI}^{+}\right)$: found 256.1184. $\mathrm{C}_{12} \mathrm{H}_{22} \mathrm{NOSSi}(\mathrm{M}+\mathrm{H})$ requires 256.1186 .

3.3.4. 5-Butyl-6-phenyl-5,6-dihydro-4H-thieno[2,3-c]pyrrol-4-one 35 and 2-Benzoyl-N-butylthiophene-3-carboxamide 36

Under a nitrogen atmosphere, $n$-butyllithium $\left(2.5 \mathrm{M}\right.$ in hexane, $\left.4.2 \mathrm{~cm}^{3}, 10.5 \mathrm{mmol}\right)$ was added dropwise to a stirred $-78{ }^{\circ} \mathrm{C}$ solution of $N$-butylthiophene-3-carboxamide 32 $(0.9158 \mathrm{~g}, 5.00 \mathrm{mmol})$ in dry $\mathrm{THF}\left(50 \mathrm{~cm}^{3}\right)$. After stirring at $-78^{\circ} \mathrm{C}$ for $5 \mathrm{~min}$, the reaction mixture was allowed to warm to $\mathrm{rt}$ for $1 \mathrm{~h}$ before benzaldehyde $\left(0.57 \mathrm{~cm}^{3}, 0.60 \mathrm{~g}, 5.61 \mathrm{mmol}\right)$ was added and stirring was continued for $18 \mathrm{~h}$. The reaction mixture was poured into sat. aq. $\mathrm{NH}_{4} \mathrm{Cl}\left(100 \mathrm{~cm}^{3}\right)$ and extracted with $\mathrm{Et}_{2} \mathrm{O}\left(3 \times 50 \mathrm{~cm}^{3}\right)$ and the combined organic layers were dried and evaporated.

The residue was dissolved in toluene $\left(100 \mathrm{~cm}^{3}\right)$ and treated with $p$-toluenesulfonic acid monohydrate $(1.90 \mathrm{~g}, 9.99 \mathrm{mmol})$ before being heated at reflux for $1 \mathrm{~h}$. After cooling to $\mathrm{rt}$, the reaction mixture was washed with water $\left(50 \mathrm{~cm}^{3}\right), 2 \mathrm{M} \mathrm{NaOH}\left(50 \mathrm{~cm}^{3}\right)$ and brine $\left(50 \mathrm{~cm}^{3}\right)$ before being dried and evaporated. The crude residue was purified by column chromatography $\left(\mathrm{SiO}_{2}, \mathrm{Et}_{2} \mathrm{O} /\right.$ hexane 3:2) to give, at $\mathrm{R}_{\mathrm{f}} 0.50,35(0.3223 \mathrm{~g}, 24 \%)$ as a pale yellow solid; mp $96-98{ }^{\circ} \mathrm{C} ; v_{\max } / \mathrm{cm}^{-1} 2953,1668,1454,1412,1375,1308,1267,1070,760$, 700 and 575; $\delta_{\mathrm{H}}(400 \mathrm{MHz}) 7.40-7.34(4 \mathrm{H}, \mathrm{m}, \mathrm{ArH}), 7.27(1 \mathrm{H}, \mathrm{d}, J$ 4.8, ArH), 7.17-7.13 (2H, $\mathrm{m}, \mathrm{ArH}), 5.51(1 \mathrm{H}, \mathrm{s}, \mathrm{CHPh}), 3.84(1 \mathrm{H}, \mathrm{dt}, J$ 14.0, 8.0, NCH), 2.81 (1H, ddd, J 14.0, 7.6, 6.4, $\mathrm{NC}), 1.53-1.45\left(2 \mathrm{H}, \mathrm{m}, \mathrm{NCH}_{2} \mathrm{CH}_{2}\right), 1.35-1.24\left(2 \mathrm{H}, \mathrm{m}, \mathrm{CH}_{2} \mathrm{CH}_{3}\right)$ and $0.88\left(3 \mathrm{H}, \mathrm{t}, \mathrm{J} 7.4, \mathrm{CH}_{3}\right)$; $\delta_{\mathrm{C}}(125 \mathrm{MHz}) 165.1(\mathrm{C}=\mathrm{O}), 155.0(\mathrm{C}), 139.8(\mathrm{C}), 136.7(\mathrm{C}), 130.2(\mathrm{CH}), 129.2(2 \mathrm{CH}), 129.0$ $(\mathrm{CH}), 127.3(2 \mathrm{CH}), 120.1(\mathrm{CH}), 62.9(\mathrm{CHPh}), 40.3\left(\mathrm{NCH}_{2}\right), 30.7\left(\mathrm{CH}_{2}\right), 20.0\left(\mathrm{CH}_{2}\right)$ and 13.7 $\left(\mathrm{CH}_{3}\right)$; HRMS (ASAP $\left.{ }^{+}\right)$: found 272.1115. $\mathrm{C}_{16} \mathrm{H}_{18} \mathrm{NOS}(\mathrm{M}+\mathrm{H})$ requires 272.1104 .

This was followed by a second fraction to give, at $R_{\mathrm{f}} 0.30,36(0.1817 \mathrm{~g}, 13 \%)$ as an orange oil; $v_{\max } / \mathrm{cm}^{-1} 3277,2957,2870,1630,1549,1449,1406,1279,847$ and $691 ; \delta_{\mathrm{H}}$ (400 MHz) 8.65 (1H, br s, NH), 7.84-7.81 (2H, m, Ph), 7.75 (1H, d, J 5.0, ArH), 7.64-7.60 (1H, $\mathrm{m}, \mathrm{Ph}), 7.55$ (1H, d, J 5.0, ArH), 7.51-7.46 (2H, m, Ph), 3.33 (2H, td, J 7.2, 5.6, $\left.\mathrm{NCH}_{2}\right), 1.56-1.49$ $\left(2 \mathrm{H}, \mathrm{m}, \mathrm{NCH}_{2} \mathrm{CH}_{2}\right), 1.42-1.33\left(2 \mathrm{H}, \mathrm{m}, \mathrm{CH}_{2} \mathrm{CH}_{3}\right)$ and $0.92\left(3 \mathrm{H}, \mathrm{t}, J 7.4, \mathrm{CH}_{3}\right) ; \delta_{\mathrm{C}}(100 \mathrm{MHz}$, signals for major amide rotamer only) $190.6(\mathrm{COPh}), 162.5(\mathrm{CONHBu}), 142.6(\mathrm{C}), 138.8(\mathrm{C})$, $138.1(\mathrm{C}), 133.3(\mathrm{CH}), 132.8(\mathrm{CH}), 130.4(\mathrm{CH}), 129.8(2 \mathrm{CH}), 128.3(2 \mathrm{CH}), 39.7\left(\mathrm{NCH}_{2}\right), 31.2$ $\left(\mathrm{CH}_{2}\right), 20.2\left(\mathrm{CH}_{2}\right)$ and $13.7\left(\mathrm{CH}_{3}\right)$; HRMS $\left(\mathrm{NSI}^{+}\right)$: found 288.1052. $\mathrm{C}_{16} \mathrm{H}_{18} \mathrm{NO}_{2} \mathrm{~S}(\mathrm{M}+\mathrm{H})$ requires 288.1053 .

\subsection{Preparation and Reactions of 4-Benzyloxy-3-thienyl Systems}

\subsubsection{Methyl 3-((2-Methoxy-2-oxoethyl)thio)propanoate 37}

Following a literature procedure [12], methyl acrylate $(18.37 \mathrm{~g}, 0.213 \mathrm{~mol})$ was added dropwise to a stirred mixture of methyl thioglycolate $(21.18 \mathrm{~g}, 0.200 \mathrm{~mol})$ and piperidine $\left(0.2 \mathrm{~cm}^{3}, 0.17 \mathrm{~g}, 2.02 \mathrm{mmol}\right)$. Once approximately half of the methyl acrylate had been added, further piperidine $\left(0.2 \mathrm{~cm}^{3}, 0.17 \mathrm{~g}, 2.02 \mathrm{mmol}\right)$ was added. Once the addition was complete, the reaction mixture was heated at $80{ }^{\circ} \mathrm{C}$ for $30 \mathrm{~min}$. After cooling to $\mathrm{rt}$, the reaction mixture was diluted with $\mathrm{Et}_{2} \mathrm{O}\left(150 \mathrm{~cm}^{3}\right)$ and washed with water $(5 \times$ $\left.50 \mathrm{~cm}^{3}\right)$ before being dried and evaporated to give $37(37.12 \mathrm{~g}, 97 \%)$ as a pale yellow oil which was used without further purification; $\delta_{\mathrm{H}}(400 \mathrm{MHz}) 3.75\left(3 \mathrm{H}, \mathrm{s}, \mathrm{CH}_{3}\right), 3.71(3 \mathrm{H}, \mathrm{s}$, $\left.\mathrm{CH}_{3}\right), 3.26\left(2 \mathrm{H}, \mathrm{s}, \mathrm{MeO}_{2} \mathrm{CCH}_{2} \mathrm{~S}\right), 2.92\left(2 \mathrm{H}, \mathrm{t}, J\right.$ 7.2, $\left.\mathrm{SCH}_{2} \mathrm{CH}_{2} \mathrm{CO}_{2} \mathrm{Me}\right)$ and $2.66(2 \mathrm{H}, \mathrm{t}, J$ J 7.2 , $\left.\mathrm{SCH}_{2} \mathrm{CH}_{2} \mathrm{CO}_{2} \mathrm{Me}\right) ; \delta_{\mathrm{C}}(100 \mathrm{MHz}) 172.0(\mathrm{C}=\mathrm{O}), 170.7(\mathrm{C}=\mathrm{O}), 52.4\left(\mathrm{CH}_{3}\right), 51.8\left(\mathrm{CH}_{3}\right), 34.1$ $\left(\mathrm{CH}_{2}\right), 33.4\left(\mathrm{CH}_{2}\right)$ and $27.5\left(\mathrm{CH}_{2}\right)$. The ${ }^{1} \mathrm{H}$ NMR spectral data were in accordance with those previously reported [11]. ${ }^{13} \mathrm{C}$ NMR data are reported for the first time.

\subsubsection{Methyl 4-Oxotetrahydrothiophene-3-carboxylate 38}

Following a literature procedure [13], sodium methoxide was prepared by the addition of sodium $(12.51 \mathrm{~g}, 0.544 \mathrm{~mol})$ in small portions to methanol $\left(90 \mathrm{~cm}^{3}\right)$. Once the sodium had fully dissolved, a solution of methyl 3-((2-methoxy-2-oxoethyl)thio)propanoate 37 
$(37.12 \mathrm{~g}, 0.193 \mathrm{~mol})$ in methanol $\left(30 \mathrm{~cm}^{3}\right)$ was added dropwise and the reaction mixture was heated at reflux for $1 \mathrm{~h}$. After cooling to rt, the reaction mixture was poured into a mixture of crushed ice $(400 \mathrm{~g})$ and conc. $\mathrm{HCl}\left(100 \mathrm{~cm}^{3}\right)$ before being extracted with $\mathrm{CH}_{2} \mathrm{Cl}_{2}$ $\left(2 \times 300 \mathrm{~cm}^{3}\right)$. The combined organic layers were washed with sat. aq. $\mathrm{NaHCO}_{3}\left(250 \mathrm{~cm}^{3}\right)$ before being dried and evaporated. The crude residue was purified by distillation to give $38(11.69 \mathrm{~g}, 38 \%)$ as a colourless oil which partially crystallised on standing; bp $103^{\circ} \mathrm{C} / 4.9$ Torr; (lit. [20] $109^{\circ} \mathrm{C} / 4$ Torr).

\subsubsection{Methyl 4-Hydroxythiophene-3-carboxylate 39}

Following a literature procedure [14], sulfuryl chloride $\left(9.7 \mathrm{~cm}^{3}, 16.15 \mathrm{~g}, 0.120 \mathrm{~mol}\right)$ was added dropwise to a stirred $0{ }^{\circ} \mathrm{C}$ solution of methyl 4-oxotetrahydrothiophene-3carboxylate $973(17.41 \mathrm{~g}, 0.109 \mathrm{~mol})$ in $\mathrm{CH}_{2} \mathrm{Cl}_{2}\left(110 \mathrm{~cm}^{3}\right)$ over a period of $1 \mathrm{~h}$. The reaction mixture was stirred at $0{ }^{\circ} \mathrm{C}$ for $30 \mathrm{~min}$ before being washed with sat. aq. $\mathrm{NaHCO}_{3}\left(150 \mathrm{~cm}^{3}\right)$ and water $\left(3 \times 50 \mathrm{~cm}^{3}\right)$. The organic layer was dried and evaporated to give after filtration through a silica plug $\left(\mathrm{Et}_{2} \mathrm{O}\right), 39(12.93 \mathrm{~g}, 75 \%)$ as a light brown low-melting solid; $\delta_{\mathrm{H}}$ $(300 \mathrm{MHz}) 8.72(1 \mathrm{H}, \mathrm{s}, \mathrm{OH}), 7.90(1 \mathrm{H}, \mathrm{d}, J 3.6, \mathrm{ArH}), 6.39(1 \mathrm{H}, \mathrm{d}, J 3.6, \mathrm{ArH})$ and $3.92(3 \mathrm{H}, \mathrm{s}$, $\left.\mathrm{CH}_{3}\right) ; \delta_{\mathrm{C}}(125 \mathrm{MHz}) 165.4(\mathrm{C}=\mathrm{O}), 155.3(\mathrm{C}-\mathrm{O}), 131.0(\mathrm{CH}), 119.0(\mathrm{C}), 100.0(\mathrm{CH})$ and 51.8 $\left(\mathrm{CH}_{3}\right)$. The ${ }^{1} \mathrm{H}$ NMR spectral data were in accordance with those previously reported [15]. ${ }^{13} \mathrm{C}$ NMR data are reported for the first time.

\subsubsection{Methyl 4-Acetoxythiophene-3-carboxylate $\mathbf{4 0}$}

Following a literature procedure [15], a mixture of methyl 4-oxotetrahydrothiophene3-carboxylate $38(30.80 \mathrm{~g}, 0.192 \mathrm{~mol})$ and $p$-toluenesulfonic acid monohydrate $(0.19 \mathrm{~g}$, $1.00 \mathrm{mmol})$ in isopropenyl acetate $\left(70 \mathrm{~cm}^{3}\right)$ was heated at reflux for $18 \mathrm{~h}$. After cooling to rt, the reaction mixture was concentrated in vacuo to give methyl 4-acetoxy-2,5dihydrothiophene-3-carboxylate as a dark brown oil which was used without further purification.

Following a literature procedure [15], sulfuryl chloride $\left(19.5 \mathrm{~cm}^{3}, 32.47 \mathrm{~g}, 0.241 \mathrm{~mol}\right)$ was added dropwise to a stirred $-25^{\circ} \mathrm{C}$ solution of methyl 4-acetoxy-2,5-dihydrothiophene3-carboxylate (assuming $0.192 \mathrm{~mol}$ ) in $\mathrm{CH}_{2} \mathrm{Cl}_{2}\left(80 \mathrm{~cm}^{3}\right)$ over a period of $1 \mathrm{~h}$. The reaction mixture was allowed to warm to $\mathrm{rt}$ for $18 \mathrm{~h}$ before being evaporated to give 40 (19.10 g, $50 \%)$ as a dark brown oil which was used without further purification; $\delta_{\mathrm{H}}(500 \mathrm{MHz}) 8.07$ $(1 \mathrm{H}, \mathrm{d}, J 33.8, \mathrm{ArH}), 6.98(1 \mathrm{H}, \mathrm{d}, J 3.8, \mathrm{ArH}), 3.83\left(3 \mathrm{H}, \mathrm{s}, \mathrm{OCH}_{3}\right)$ and $2.33\left(3 \mathrm{H}, \mathrm{s}, \mathrm{COCH}_{3}\right)$. The ${ }^{1} \mathrm{H}$ NMR spectral data were in accordance with those previously reported [15].

\subsubsection{Silver(I) Oxide}

A solution of sodium hydroxide $(14.61 \mathrm{~g}, 0.365 \mathrm{~mol})$ in water $\left(440 \mathrm{~cm}^{3}\right)$ was added dropwise to a stirred solution of silver nitrate $(60.00 \mathrm{~g}, 0.353 \mathrm{~mol})$ in water $\left(110 \mathrm{~cm}^{3}\right)$. Once the addition was complete, the precipitate was collected by filtration and washed with water until the washings were neutral before being dried in vacuo to give the title compound (39.60 g, 97\%) as a brown solid which was stored in the dark and used without further purification.

\subsubsection{Methyl 4-(Benzyloxy)thiophene-3-carboxylate $\mathbf{4 1}$}

A mixture of methyl 4-hydroxythiophene-3-carboxylate $39(12.91 \mathrm{~g}, 81.6 \mathrm{mmol})$, silver(I) oxide $(28.40 \mathrm{~g}, 0.123 \mathrm{~mol})$ and benzyl bromide $\left(10.7 \mathrm{~cm}^{3}, 15.39 \mathrm{~g}, 90.0 \mathrm{mmol}\right)$ in $\mathrm{CH}_{2} \mathrm{Cl}_{2}\left(500 \mathrm{~cm}^{3}\right)$ was heated at reflux for $3 \mathrm{~d}$. After cooling to rt, the reaction mixture was filtered and evaporated and the crude residue was purified by column chromatography $\left(\mathrm{SiO}_{2}, \mathrm{Et}_{2} \mathrm{O} /\right.$ hexane 1:1) to give, at $\mathrm{R}_{\mathrm{f}} 0.90,983(5.47 \mathrm{~g}, 27 \%)$ as a red oil; $\nu_{\max } / \mathrm{cm}^{-1} 3113$, 2949, 1726, 1541, 1449, 1265, 1082, 770 and 698; $\delta_{\mathrm{H}}(500 \mathrm{MHz}) 8.01(1 \mathrm{H}, \mathrm{d}, J 3.5, \mathrm{ArH}), 7.48$ $(2 \mathrm{H}, \mathrm{d}, J$ 7.5, Ph), $7.38(2 \mathrm{H}, \mathrm{t}, J$ 7.5, Ph), $7.31(1 \mathrm{H}, \mathrm{t}, J$ 7.5, Ph), 6.31 (1H, d, J 3.5, ArH), 5.13 $\left(2 \mathrm{H}, \mathrm{s}, \mathrm{CH}_{2}\right)$ and $3.86\left(3 \mathrm{H}, \mathrm{s}, \mathrm{CH}_{3}\right) ; \delta_{\mathrm{C}}(125 \mathrm{MHz}) 162.2(\mathrm{C}=\mathrm{O}), 156.1(\mathrm{C}-\mathrm{O}), 136.5(\mathrm{C}), 133.2$ $(\mathrm{CH}), 128.5(2 \mathrm{CH}), 127.8(\mathrm{CH}), 126.8(2 \mathrm{CH}), 123.7(\mathrm{C}), 99.9(\mathrm{CH}), 72.3\left(\mathrm{CH}_{2}\right)$ and $51.6\left(\mathrm{CH}_{3}\right)$; HRMS $\left(\mathrm{ESI}^{+}\right)$: found 271.0393. $\mathrm{C}_{13} \mathrm{H}_{12} \mathrm{NaO}_{3} \mathrm{~S}(\mathrm{M}+\mathrm{Na})$ requires 271.0399 . 


\subsubsection{4-(Benzyloxy)thiophene-3-carboxylic Acid $\mathbf{4 2}$}

A mixture of methyl 4-(benzyloxy)thiophene-3-carboxylate 41 (5.17 g, $20.8 \mathrm{mmol})$ and sodium hydroxide $(1.74 \mathrm{~g}, 43.5 \mathrm{mmol})$ in water $\left(45 \mathrm{~cm}^{3}\right)$ was heated at reflux for $18 \mathrm{~h}$. After cooling to rt, the reaction mixture was washed with $\mathrm{CH}_{2} \mathrm{Cl}_{2}\left(30 \mathrm{~cm}^{3}\right)$ before being adjusted to $\mathrm{pH} 1$ by the addition of $2 \mathrm{M} \mathrm{HCl}$ and extracted with $\mathrm{CH}_{2} \mathrm{Cl}_{2}\left(2 \times 50 \mathrm{~cm}^{3}\right)$. The combined organic extracts were dried and evaporated to give, after recrystallisation (PhMe), 42 (3.08 g, 63\%) as brown crystals; $\mathrm{mp} 101-105^{\circ} \mathrm{C} ; v_{\max } / \mathrm{cm}^{-1} 3123,1667,1537$, $1447,1285,1196,1088,880$ and $764 ; \delta_{\mathrm{H}}(500 \mathrm{MHz}) 9.96\left(1 \mathrm{H}, \mathrm{br} \mathrm{s}, \mathrm{CO}_{2} \mathrm{H}\right), 8.21(1 \mathrm{H}, \mathrm{d}, J 3.5$, $\mathrm{ArH}), 7.45-7.37(5 \mathrm{H}, \mathrm{m}, \mathrm{Ph}), 6.48(1 \mathrm{H}, \mathrm{d}, J 3.5, \mathrm{ArH})$ and $5.20\left(2 \mathrm{H}, \mathrm{s}, \mathrm{CH}_{2}\right) ; \delta_{\mathrm{C}}(125 \mathrm{MHz})$ $164.7(\mathrm{C}=\mathrm{O}), 155.0(\mathrm{C}-\mathrm{O}), 135.5(\mathrm{C}), 135.2(\mathrm{CH}), 128.6(2 \mathrm{CH}), 128.3 \mathrm{CH}), 127.2(2 \mathrm{CH}), 122.7$ (C), $100.4(\mathrm{CH})$ and $72.9\left(\mathrm{CH}_{2}\right)$; HRMS $\left(\mathrm{ESI}^{+}\right)$: found 257.0239. $\mathrm{C}_{12} \mathrm{H}_{10} \mathrm{NaO}_{3} \mathrm{~S}(\mathrm{M}+\mathrm{Na})$ requires 257.0243 .

\subsubsection{4-(Benzyloxy)-N-(1-hydroxy-2-methylpropan-2-yl)thiophene-3-carboxamide 43}

Thionyl chloride $\left(0.31 \mathrm{~cm}^{3}, 0.51 \mathrm{~g}, 4.25 \mathrm{mmol}\right)$ was added to a suspension of 4(benzyloxy)thiophene-3-carboxylic acid $42(0.50 \mathrm{~g}, 2.13 \mathrm{mmol})$ in toluene $\left(5 \mathrm{~cm}^{3}\right)$ and the mixture was heated under reflux for $3 \mathrm{~h}$. After cooling to rt, the mixture was evaporated to give 4-(benzyloxy)thiophene-3-carbonyl chloride as a red oil which was used immediately without further purification.

A solution of 4-(benzyloxy)thiophene-3-carbonyl chloride (assuming $2.13 \mathrm{mmol}$ ) in $\mathrm{CH}_{2} \mathrm{Cl}_{2}\left(30 \mathrm{~cm}^{3}\right)$ was added dropwise to a solution of 2-amino-2-methylpropan-1-ol (0.41 g, $4.60 \mathrm{mmol})$ in $\mathrm{CH}_{2} \mathrm{Cl}_{2}\left(10 \mathrm{~cm}^{3}\right)$ stirred at $0{ }^{\circ} \mathrm{C}$. After the addition, the mixture was allowed to warm to $\mathrm{rt}$ and stirred for $18 \mathrm{~h}$ before being poured into water. The organic layer was separated and the aqueous layer extracted with $\mathrm{CH}_{2} \mathrm{Cl}_{2}\left(2 \times 20 \mathrm{~cm}^{3}\right)$. The combined organic layers were washed successively with $2 \mathrm{M} \mathrm{HCl}, 2 \mathrm{M} \mathrm{NaOH}$ and water before being dried and evaporated to give $43(0.60 \mathrm{~g}, 92 \%)$ as a pale-yellow solid which was used without further purification; $\mathrm{mp} 90-92{ }^{\circ} \mathrm{C} ; v_{\max } / \mathrm{cm}^{-1} 3366,2970,1628,1560,1435,1364$, $1310,1074,976$ and $606 ; \delta_{\mathrm{H}}(400 \mathrm{MHz}) 8.07(1 \mathrm{H}, \mathrm{d}, J 3.6, \mathrm{ArH}), 7.65(1 \mathrm{H}, \mathrm{br} \mathrm{s}, \mathrm{NH}), 7.46-7.37$ $(5 \mathrm{H}, \mathrm{m}, \mathrm{Ph}), 6.46(1 \mathrm{H}, \mathrm{d}, J 3.6, \mathrm{ArH}), 5.22(1 \mathrm{H}, \mathrm{br} \mathrm{s}, \mathrm{OH}), 5.08\left(2 \mathrm{H}, \mathrm{s}, \mathrm{OCH}_{2} \mathrm{Ph}\right), 3.57(2 \mathrm{H}, \mathrm{s}$, $\left.\mathrm{CH}_{2} \mathrm{OH}\right)$ and $1.16\left(6 \mathrm{H}, \mathrm{s}, \mathrm{CH}_{3}\right) ; \delta_{\mathrm{C}}(100 \mathrm{MHz}) 162.1(\mathrm{C}=\mathrm{O}), 153.1(\mathrm{C}-\mathrm{O}), 135.1(\mathrm{C}), 131.9$ $(\mathrm{CH}), 128.8(\mathrm{CH}), 128.7(2 \mathrm{CH}), 128.1(2 \mathrm{CH}), 126.6(\mathrm{C}), 99.7(\mathrm{CH}), 73.2\left(\mathrm{CH}_{2}\right), 70.7\left(\mathrm{CH}_{2}\right), 56.0$ $\left(\mathrm{CMe}_{2}\right)$ and $24.5\left(2 \mathrm{CH}_{3}\right)$; HRMS $\left(\mathrm{NSI}^{+}\right)$: found 306.1150. $\mathrm{C}_{16} \mathrm{H}_{20} \mathrm{NO}_{3} \mathrm{~S}(\mathrm{M}+\mathrm{H})$ requires 306.1158.

\subsubsection{2-(4-(Benzyloxy)thiophen-3-yl)-4,4-dimethyl-4,5-dihydrooxazole 13}

Thionyl chloride $\left(0.15 \mathrm{~cm}^{3}, 0.24 \mathrm{~g}, 2.06 \mathrm{mmol}\right)$ was added to a solution of 4-(benzyloxy)$\mathrm{N}$-(1-hydroxy-2-methylpropan-2-yl)thiophene-3-carboxamide 43 (0.50 g, $1.64 \mathrm{mmol}$ ) in $\mathrm{CH}_{2} \mathrm{Cl}_{2}\left(20 \mathrm{~cm}^{3}\right)$ and the mixture was stirred at $\mathrm{rt}$ for $18 \mathrm{~h}$. The mixture was washed with $2 \mathrm{M} \mathrm{NaOH}$ and water before being dried and evaporated to give, after purification by column chromatography $\left(\mathrm{SiO}_{2}, \mathrm{Et}_{2} \mathrm{O} /\right.$ hexane 3:2), at $\mathrm{R}_{\mathrm{f}} 0.40,13(0.41 \mathrm{~g}, 87 \%)$ as a pale yellow solid; $\mathrm{mp} 77-80^{\circ} \mathrm{C} ; v_{\max } / \mathrm{cm}^{-1} 2965,1651,1535,1449,1371,1211,1194,1042,733$ and 698; $\delta_{\mathrm{H}}(400 \mathrm{MHz}) 7.79(1 \mathrm{H}, \mathrm{d}, J 33.6, \mathrm{ArH}), 7.47(2 \mathrm{H}, \mathrm{d}, J$ J 7.6, Ph), $7.36(2 \mathrm{H}, \mathrm{t}, J$ 7.4, Ph), $7.29\left(1 \mathrm{H}, \mathrm{t}, J\right.$ 7.2, Ph), $6.30(1 \mathrm{H}, \mathrm{d}, J$ J 3.6, ArH $), 5.16\left(2 \mathrm{H}, \mathrm{s}, \mathrm{OCH}_{2} \mathrm{Ph}\right), 4.05\left(2 \mathrm{H}, \mathrm{s}, \mathrm{OCH}_{2}\right)$ and $1.39\left(6 \mathrm{H}, \mathrm{s}, \mathrm{CH}_{3}\right) ; \delta_{\mathrm{C}}(100 \mathrm{MHz}) 157.2(\mathrm{C}), 155.3(\mathrm{C}), 136.9(\mathrm{C}), 129.1(\mathrm{CH}), 128.4(2 \mathrm{CH})$, 127.6 CH), $126.7(2 \mathrm{CH}), 121.6(\mathrm{C}), 100.3(\mathrm{CH}), 78.5\left(\mathrm{OCH}_{2}\right), 72.4\left(\mathrm{OCH}_{2}\right), 67.5\left(\mathrm{CMe}_{2}\right)$ and $28.4\left(2 \mathrm{CH}_{3}\right)$; HRMS $\left(\mathrm{ESI}^{+}\right)$: found 288.1047. $\mathrm{C}_{16} \mathrm{H}_{18} \mathrm{NO}_{2} \mathrm{~S}(\mathrm{M}+\mathrm{H})$ requires 288.1053.

\subsubsection{4-((1-Hydroxy-2-methylpropan-2-yl)carbamoyl)thiophen-3-yl Benzoate 45}

Under a nitrogen atmosphere, $n$-butyllithium $\left(2.5 \mathrm{M}\right.$ in hexanes, $\left.0.88 \mathrm{~cm}^{3}, 2.20 \mathrm{mmol}\right)$ was added to a stirred mixture of 2-(4-(benzyloxy)thiophen-3-yl)-4,4-dimethyl-4,5dihydrooxazole $13(0.1443 \mathrm{~g}, 0.50 \mathrm{mmol})$ and potassium tert-butoxide $(0.2485 \mathrm{~g}, 2.21 \mathrm{mmol})$ in dry THF $\left(5 \mathrm{~cm}^{3}\right)$. The mixture was stirred at $\mathrm{rt}$ for $2 \mathrm{~h}$ before being quenched by the addition of saturated aq. $\mathrm{NH}_{4} \mathrm{Cl}$ and extracted with $\mathrm{Et}_{2} \mathrm{O}\left(3 \times 10 \mathrm{~cm}^{3}\right)$. The combined extracts were dried and evaporated to give, after purification by preparative TLC $\left(\mathrm{Al}_{2} \mathrm{O}_{3}\right.$, 
$\mathrm{Et}_{2} \mathrm{O} /$ hexane $\left.1: 1\right)$, at $\mathrm{R}_{\mathrm{f}} 0.35,45(55.8 \mathrm{mg}, 35 \%)$ in slightly impure form as a brown oil; $v_{\max } / \mathrm{cm}^{-1} 3335,2972,1744,1638,1545,1450,1246,1177,1047,908,766$ and $700 ; \delta_{\mathrm{H}}$ (400 MHz) 8.19-8.16 (2H, m, Ph), 7.99 (1H, d, J 3.6, ArH), 7.71-7.67 (1H, m, Ph), $7.55(2 \mathrm{H}, \mathrm{t}$, J 7.8, Ph), $7.34(1 \mathrm{H}, \mathrm{d}, J 3.6, \mathrm{ArH}), 6.61\left(1 \mathrm{H}\right.$, br s, NH), $4.58\left(1 \mathrm{H}\right.$, br s, OH), $3.59\left(2 \mathrm{H}, \mathrm{s}, \mathrm{CH}_{2}\right)$ and $1.24\left(6 \mathrm{H}, \mathrm{s}, \mathrm{CH}_{3}\right) ; \delta_{\mathrm{C}}(125 \mathrm{MHz}) 163.7(\mathrm{CO}), 162.2(\mathrm{CO}), 143.2(\mathrm{C}), 134.4(\mathrm{CH}), 130.0$ $(2 \mathrm{CH}), 129.9(\mathrm{CH}), 129.3(\mathrm{C}), 128.9(2 \mathrm{CH}), 128.4(\mathrm{C}), 113.7(\mathrm{CH}), 69.9\left(\mathrm{OCH}_{2}\right), 56.3\left(\mathrm{CMe}_{2}\right)$ and $24.6\left(2 \mathrm{CH}_{3}\right)$; HRMS $\left(\mathrm{NSI}^{+}\right)$: found 320.0953. $\mathrm{C}_{16} \mathrm{H}_{18} \mathrm{NO}_{4} \mathrm{~S}(\mathrm{M}+\mathrm{H})$ requires 320.0951 .

\subsubsection{4-(Benzyloxy)-N-butylthiophene-3-carboxamide 14}

Thionyl chloride $\left(1.0 \mathrm{~cm}^{3}, 1.63 \mathrm{~g}, 13.7 \mathrm{mmol}\right)$ was added to a suspension of 4(benzyloxy)thiophene-3-carboxylic acid $42(1.50 \mathrm{~g}, 6.40 \mathrm{mmol})$ in toluene $\left(15 \mathrm{~cm}^{3}\right)$ and the mixture was heated under reflux for $3 \mathrm{~h}$. After cooling to $\mathrm{rt}$, the mixture was evaporated to give 4-(benzyloxy)thiophene-3-carbonyl chloride as a red oil which was used immediately without further purification.

A solution of 4-(benzyloxy)thiophene-3-carbonyl chloride (assuming $6.40 \mathrm{mmol}$ ) in toluene $\left(30 \mathrm{~cm}^{3}\right)$ was added dropwise to a solution of $n$-butylamine $\left(1.9 \mathrm{~cm}^{3}, 1.41 \mathrm{~g}\right.$, $19.2 \mathrm{mmol})$ in toluene $\left(10 \mathrm{~cm}^{3}\right)$ stirred at $0{ }^{\circ} \mathrm{C}$. Once the addition was complete, the reaction mixture was allowed to warm to rt over $1 \mathrm{~h}$ before being poured into water. The organic layer was separated and washed with $2 \mathrm{M} \mathrm{NaOH}$ and brine, dried and evaporated to give, after purification by column chromatography $\left(\mathrm{SiO}_{2}, \mathrm{Et}_{2} \mathrm{O} /\right.$ hexane 3:2), at $\mathrm{R}_{\mathrm{f}} 0.50,14(1.24 \mathrm{~g}$, $67 \%$ ) as a tan-coloured solid; $\operatorname{mp} 51-53^{\circ} \mathrm{C} ; v_{\max } / \mathrm{cm}^{-1} 3385,3111,2970,1630,1557,1435$, $1364,1265,1184,1074,988,714$ and 579; $\delta_{\mathrm{H}}(400 \mathrm{MHz}) 8.10(1 \mathrm{H}, \mathrm{d}, J 3.6, \mathrm{ArH}), 7.45-7.37$ $(6 \mathrm{H}, \mathrm{m}, \mathrm{NH}$ and $\mathrm{Ph}), 6.43(1 \mathrm{H}, \mathrm{d}, J 3.6, \mathrm{ArH}), 5.10\left(2 \mathrm{H}, \mathrm{s}, \mathrm{OCH}_{2}\right), 3.34(2 \mathrm{H}, \mathrm{td}, J$ 6.8, 5.6, $\left.\mathrm{NCH}_{2}\right), 1.45-1.38\left(2 \mathrm{H}, \mathrm{m}, \mathrm{NCH}_{2} \mathrm{CH}_{2}\right), 1.25-1.15\left(2 \mathrm{H}, \mathrm{m}, \mathrm{CH}_{2} \mathrm{CH}_{3}\right)$ and $0.81(3 \mathrm{H}, \mathrm{t}, J$ 7.2, $\left.\mathrm{CH}_{3}\right) ; \delta_{\mathrm{C}}(100 \mathrm{MHz}) 161.5(\mathrm{C}=\mathrm{O}), 153.5(\mathrm{C}-\mathrm{O}), 135.5(\mathrm{C}), 131.5(\mathrm{CH}), 128.8(2 \mathrm{CH}), 128.7$ $(\mathrm{CH}), 127.9(2 \mathrm{CH}), 127.1(\mathrm{C}), 99.5(\mathrm{CH}), 73.1\left(\mathrm{OCH}_{2}\right), 38.7\left(\mathrm{NCH}_{2}\right), 31.3\left(\mathrm{CH}_{2}\right), 20.0\left(\mathrm{CH}_{2}\right)$ and $13.7\left(\mathrm{CH}_{3}\right)$; HRMS (NSI ${ }^{+}$): found 290.1207. $\mathrm{C}_{16} \mathrm{H}_{20} \mathrm{NO}_{2} \mathrm{~S}(\mathrm{M}+\mathrm{H})$ requires 290.1209 .

3.4.12. Attempted [1,2]-Wittig Rearrangement of 4-(Benzyloxy)-N-butylthiophene-3carboxamide 14

Under a nitrogen atmosphere, $n$-butyllithium $\left(2.5 \mathrm{M}, 2.7 \mathrm{~cm}^{3}, 6.75 \mathrm{mmol}\right)$ was added dropwise to a stirred solution of 4-(benzyloxy)- $N$-butylthiophene-3-carboxamide 14 $(0.5787 \mathrm{~g}, 2.00 \mathrm{mmol})$ in dry THF $\left(20 \mathrm{~cm}^{3}\right)$. After stirring at $\mathrm{rt}$ for $2 \mathrm{~h}$, the reaction mixture was quenched by the addition of saturated aq. $\mathrm{NH}_{4} \mathrm{Cl}$ and extracted with $\mathrm{Et}_{2} \mathrm{O}\left(3 \times 30 \mathrm{~cm}^{3}\right)$. The combined organic extracts were washed with $\mathrm{NaOH}$ and water before being dried and evaporated to give, after purification by column chromatography $\left(\mathrm{SiO}_{2}, \mathrm{Et}_{2} \mathrm{O} /\right.$ hexane 3:2), at $\mathrm{R}_{\mathrm{f}}$ 0.65, 4-(benzyloxy)-N-butyl-2-(hydroxy(phenyl)methyl)thiophene-3-carboxamide 46 $(27.8 \mathrm{mg}, 4 \%)$ in slightly impure form as a tan-coloured solid; $\mathrm{mp} 74-76{ }^{\circ} \mathrm{C} ; v_{\max } / \mathrm{cm}^{-1}$ $3393,3084,2930,2870,1624,1557,1443,1217,1173,1016$ and $696 ; \delta_{\mathrm{H}}(400 \mathrm{MHz}) 7.73(1 \mathrm{H}$, t, J 5.0, NH), 7.52-7.48 (2H, m, Ph), 7.44-7.30 (8H, m, Ph), $6.77(1 \mathrm{H}, \mathrm{br} \mathrm{s}, \mathrm{OH}), 6.26(1 \mathrm{H}, \mathrm{s}$, $\mathrm{ArH}), 6.21(1 \mathrm{H}, \mathrm{s}, \mathrm{CHOH}), 5.04\left(2 \mathrm{H}, \mathrm{s}, \mathrm{OCH}_{2}\right), 3.41-3.25\left(2 \mathrm{H}, \mathrm{m}, \mathrm{NCH}_{2}\right), 1.42-1.35(2 \mathrm{H}, \mathrm{m}$, $\left.\mathrm{NCH}_{2} \mathrm{CH}_{2}\right), 1.21-1.12\left(2 \mathrm{H}, \mathrm{m}, \mathrm{CH}_{2} \mathrm{CH}_{3}\right)$ and $0.80\left(3 \mathrm{H}, \mathrm{t}, J 7.2, \mathrm{CH}_{3}\right) ; \delta_{\mathrm{C}}(100 \mathrm{MHz}) 163.6$ $(\mathrm{C}=\mathrm{O}), 155.9(\mathrm{C}), 154.3(\mathrm{C}), 140.9(\mathrm{C}), 135.2(\mathrm{C}), 128.8(3 \mathrm{CH}), 128.03(2 \mathrm{CH}), 128.01(2 \mathrm{CH})$, $127.97(\mathrm{CH}), 127.3(2 \mathrm{CH}), 121.9(\mathrm{C}), 97.5(\mathrm{CH}), 73.0\left(\mathrm{OCH}_{2}\right), 70.8(\mathrm{CHOH}), 39.0\left(\mathrm{NCH}_{2}\right)$, $31.0\left(\mathrm{CH}_{2}\right), 19.9\left(\mathrm{CH}_{2}\right)$ and $13.7\left(\mathrm{CH}_{3}\right)$; HRMS $\left(\mathrm{ESI}^{+}\right)$: found 418.1439. $\mathrm{C}_{23} \mathrm{H}_{25} \mathrm{NaNO}_{3} \mathrm{~S}(\mathrm{M}+$ $\mathrm{Na})$ requires 418.1447 .

This was followed by a second fraction at $R_{f} 0.50$ which was further purified by preparative TLC $\left(\mathrm{SiO}_{2}, \mathrm{CH}_{2} \mathrm{Cl}_{2}\right)$ to give, at $\mathrm{R}_{\mathrm{f}} 0.35 \mathrm{~N}$-butyl-4-hydroxythiophene-3-carboxamide $47(30.9 \mathrm{mg}, 8 \%)$ in slightly impure form as a brown oil; $v_{\max } / \mathrm{cm}^{-1} 3327,2957,2930,1634$, $1557,1441,1273,739$ and $698 ;{ }^{1} \mathrm{H}$ NMR revealed a $3: 2$ mixture of enol and keto tautomers; $\delta_{\mathrm{H}}(500 \mathrm{MHz}$, enol tautomer 47) $10.36(1 \mathrm{H}$, br s, OH), $7.54(1 \mathrm{H}, \mathrm{d}, J 3.3, \mathrm{ArH}), 6.36(1 \mathrm{H}, \mathrm{d}, J$ 3.3, $\mathrm{ArH}), 6.35(1 \mathrm{H}, \mathrm{br} \mathrm{s}, \mathrm{NH}), 3.41\left(2 \mathrm{H}, \mathrm{td}, J\right.$ 7.3, 6.0, $\left.\mathrm{NCH}_{2}\right), 1.62-1.51\left(2 \mathrm{H}, \mathrm{m}, \mathrm{NCH}_{2} \mathrm{CH}_{2}\right)$, 1.44-1.33 $\left(2 \mathrm{H}, \mathrm{m}, \mathrm{CH}_{2} \mathrm{CH}_{3}\right)$ and $0.95\left(3 \mathrm{H}, \mathrm{t}, J 7.5, \mathrm{CH}_{3}\right) ; \delta_{\mathrm{C}}(125 \mathrm{MHz}$, enol tautomer 47) $165.1(\mathrm{C}=\mathrm{O}), 156.1(\mathrm{C}-\mathrm{O}), 124.6(\mathrm{CH}), 121.7(\mathrm{C}), 100.1(\mathrm{CH}), 39.1\left(\mathrm{NCH}_{2}\right), 31.6\left(\mathrm{CH}_{2}\right), 20.08$ $\left(\mathrm{CH}_{2}\right)$ and $13.7\left(\mathrm{CH}_{3}\right) ; \delta_{\mathrm{H}}(500 \mathrm{MHz}$, keto tautomer 47a) $9.33(1 \mathrm{H}, \mathrm{s}, \mathrm{CH}), 8.06(1 \mathrm{H}$, br 
$\mathrm{s}, \mathrm{NH}), 3.89\left(2 \mathrm{H}, \mathrm{s}, \mathrm{SCH}_{2}\right), 3.36\left(2 \mathrm{H}, \mathrm{td}, J\right.$ 7.0, 6.0, $\left.\mathrm{NCH}_{2}\right), 1.62-1.51\left(2 \mathrm{H}, \mathrm{m}, \mathrm{NCH}_{2} \mathrm{CH}_{2}\right)$, 1.44-1.33 (2H, m, $\left.\mathrm{CH}_{2} \mathrm{CH}_{3}\right)$ and $0.93\left(3 \mathrm{H}, \mathrm{t}, \mathrm{J} 7.3, \mathrm{CH}_{3}\right) ; \delta_{\mathrm{C}}(125 \mathrm{MHz}$, keto tautomer 47a) $199.9(\mathrm{C}=\mathrm{O}), 174.7(\mathrm{CH}), 159.9(\mathrm{CONH}), 128.2(\mathrm{C}), 42.7\left(\mathrm{SCH}_{2}\right), 38.7\left(\mathrm{NCH}_{2}\right), 31.5\left(\mathrm{CH}_{2}\right)$, $20.11\left(\mathrm{CH}_{2}\right)$ and $13.7\left(\mathrm{CH}_{3}\right)$; HRMS $\left(\mathrm{NSI}^{+}\right)$: found 200.0740. $\mathrm{C}_{9} \mathrm{H}_{14} \mathrm{NO}_{2} \mathrm{~S}(\mathrm{M}+\mathrm{H})$ requires 200.0740 .

\subsection{X-ray Structure Determination}

Data have been deposited at the Cambridge Crystallographic Data Centre as CCDC 2111424 (9), 2111425 (20), 2111426 (11), 2111427 (26) and 2111428 (13). The data can be obtained free of charge from the Cambridge Crystallographic Data Centre via http: / / www.ccdc.cam.ac.uk/getstructures. In all cases, data were collected on a Rigaku XtaLAB 200 diffractometer using graphite monochromated Mo-K $\alpha$ radiation, $\lambda=0.71075 \AA$ and the structures were solved by direct methods and refined by full-matrix least-squares against F2 (SHELXL Version 2014/7 [21]).

\section{Compound 20}

Slow evaporation of an acetone $/ \mathrm{CH}_{2} \mathrm{Cl}_{2}$ solution gave tan-coloured crystals suitable for X-ray structure determination. Crystal data for 20: $2 \mathrm{C}_{16} \mathrm{H}_{17} \mathrm{NO}_{3} \mathrm{~S} \bullet \mathrm{CH}_{2} \mathrm{Cl}_{2} \bullet \mathrm{Me}_{2} \mathrm{CO}$, $\mathrm{M}=749.76$, yellow prism, crystal dimensions $0.10 \times 0.10 \times 0.10 \mathrm{~mm}$, monoclinic, space group $\mathrm{P} 2{ }_{1} / \mathrm{n}, \mathrm{a}=17.4520, \mathrm{~b}=9.9840, \mathrm{c}=21.1050 \AA, \beta=92.3760^{\circ}, \mathrm{V}=3674.1899 \AA^{3}, \mathrm{Z}=4$, $\mathrm{D}_{\mathrm{c}}=1.355 \mathrm{Mg} \mathrm{m}^{-3}, \mathrm{~T}=93 \mathrm{~K}, \mathrm{R}=0.0929, \mathrm{R}_{\mathrm{W}}=0.2464$ for 4473 reflections with $\mathrm{I}>2 \sigma(\mathrm{I})$ and 458 variables.

Compound 26

Slow evaporation of a $\mathrm{CH}_{2} \mathrm{Cl}_{2}$ solution gave crystals suitable for $\mathrm{X}$-ray structure determination. Crystal data for 26: $\mathrm{C}_{16} \mathrm{H}_{17} \mathrm{NOS}, \mathrm{M}=271.38$, colourless needle, crystal dimensions $0.12 \times 0.02 \times 0.02 \mathrm{~mm}$, monoclinic, space group P2 $1, \mathrm{a}=8.237(3), \mathrm{b}=5.717(2)$, $c=15.097(6) \AA, \beta=90.539(10)^{\circ}, \mathrm{V}=710.9(5) \AA^{3}, \mathrm{Z}=2, \mathrm{D}_{\mathrm{c}}=1.268 \mathrm{Mg} \mathrm{m}^{-3}, \mathrm{~T}=93 \mathrm{~K}$, $\mathrm{R}=0.0481, \mathrm{R}_{\mathrm{W}}=0.1086$ for 2072 reflections with $\mathrm{I}>2 \sigma(\mathrm{I})$ and 172 variables.

Compound 9

Slow evaporation of an MeCN solution gave crystals suitable for X-ray structure determination. Crystal data for 9: $\mathrm{C}_{16} \mathrm{H}_{17} \mathrm{NO}_{2} \mathrm{~S}, \mathrm{M}=287.38$, colourless plate, crystal dimensions $0.10 \times 0.10 \times 0.01 \mathrm{~mm}$, monoclinic, space group $\mathrm{P} 2{ }_{1} / \mathrm{c}, \mathrm{a}=15.9970(19), \mathrm{b}=7.5839(6)$, $\mathrm{c}=12.4523(15) \AA, \beta=111.010(14)^{\circ}, \mathrm{V}=1410.3(3) \AA^{3}, \mathrm{Z}=4, \mathrm{D}_{\mathrm{c}}=1.353 \mathrm{Mg} \mathrm{m}^{-3}, \mathrm{~T}=93 \mathrm{~K}$, $\mathrm{R}=0.0584, \mathrm{R}_{\mathrm{W}}=0.1406$ for 2462 reflections with $\mathrm{I}>2 \sigma(\mathrm{I})$ and 181 variables.

Compound 11

Slow evaporation of a $\mathrm{CH}_{2} \mathrm{Cl}_{2}$ solution gave crystals suitable for $\mathrm{X}$-ray structure determination. Crystal data for 11: $\mathrm{C}_{16} \mathrm{H}_{17} \mathrm{NO}_{2} \mathrm{~S}, \mathrm{M}=287.38$, colourless prism, crystal dimensions $0.12 \times 0.10 \times 0.06 \mathrm{~mm}$, monoclinic, space group $\mathrm{P} 2{ }_{1} / \mathrm{c}, \mathrm{a}=14.8176(4), \mathrm{b}=8.72450(17)$, $c=11.9720(3) \AA, \beta=113.314(3)^{\circ}, \mathrm{V}=1421.32(7) \AA^{3}, \mathrm{Z}=4, \mathrm{D}_{\mathrm{c}}=1.343 \mathrm{Mg} \mathrm{m}^{-3}, \mathrm{~T}=93 \mathrm{~K}$, $\mathrm{R}=0.0274, \mathrm{R}_{\mathrm{W}}=0.0730$ for 2906 reflections with $\mathrm{I}>2 \sigma(\mathrm{I})$ and 181 variables.

Compound 13

Slow evaporation of a toluene solution gave crystals suitable for X-ray structure determination. Crystal data for 13 : $\mathrm{C}_{16} \mathrm{H}_{17} \mathrm{NO}_{2} \mathrm{~S}, \mathrm{M}=287.38$, colourless plate, crystal dimensions $0.20 \times 0.20 \times 0.01 \mathrm{~mm}$, monoclinic, space group P2 $1 / \mathrm{c}, \mathrm{a}=15.6319(4), \mathrm{b}=8.7152(3)$, $c=10.7572(3) \AA, \beta=93.909(3)^{\circ}, \mathrm{V}=1462.10(7) \AA^{3}, Z=4, \mathrm{D}_{\mathrm{c}}=1.305 \mathrm{Mg} \mathrm{m}^{-3}, \mathrm{~T}=296 \mathrm{~K}$, $\mathrm{R}=0.0333, \mathrm{R}_{\mathrm{W}}=0.0888$ for 2781 reflections with $\mathrm{I}>2 \sigma(\mathrm{I})$ and 181 variables.

\section{Conclusions}

The three isomeric thienyloxazolines showed a varied and interesting pattern of reactivity with two of them undergoing Wittig rearrangement and two giving products derived from ring cleavage of an intermediate 3-aminothienofuran. One of the corresponding thienyl amides also underwent Wittig rearrangement and cyclisation of the product, as well as an isomeric one obtained by other means, gave two isomeric thienopyrrolones. The pattern of reactivity in the oxazoline series correlates well with the molecular geometry in the solid state as determined by X-ray diffraction, and the use of this method to 
explain patterns of competing reactivity between closely similar molecules may be useful more generally.

Supplementary Materials: The following are available online, Figures S1-S41: NMR spectra of new compounds. Cif and check-cif files for X-ray structures of 9, 11, 13, 20 and 26.

Author Contributions: A.D.H. performed the experiments; A.M.Z.S. collected the X-ray data and solved the structures; R.A.A. designed the experiments, analysed the data and wrote the paper. All authors have read and agreed to the published version of the manuscript.

Funding: We thank EPSRC (UK) for a DTA studentship to ADH (Grant EP/L505079/1) and the EPSRC UK National Mass Spectrometry Facility at Swansea University.

Institutional Review Board Statement: Not applicable.

Informed Consent Statement: Not applicable.

Data Availability Statement: The X-ray data is deposited at CCDC as stated above and all NMR spectroscopic data is in the Supplementary Material.

Conflicts of Interest: The authors declare no conflict of interest.

\section{References}

1. Aitken, R.A.; Harper, A.D.; Slawin, A.M.Z. Base-Induced Cyclisation of ortho-Substituted 2-Phenyloxazolines to Give 3Aminobenzofurans and Related Heterocycles. Synlett 2017, 28, 1738-1742. [CrossRef]

2. Gewald, K.; Jänsch, H.-J. 3-Amino-benzo[b]furane. J. Prakt. Chem. 1973, 315, 779-785. [CrossRef]

3. Schorigin, P. Über die Carbinol-Umlagerung von Benzyläthern I. Ber. Dtsch. Chem. Ges. 1924, 57, 1634-1637. [CrossRef]

4. Wang, F.; Wang, J.; Zhang, Y.; Yang, J. The [1,2]- and [1,4]-Wittig rearrangement. Tetrahedron 2020, 76, 130857. [CrossRef]

5. Etter, M.C.; Macdonald, J.C.; Bernstein, J. Graph-set analysis of hydrogen-bond patterns in organic crystals. Acta Crystallogr. B. 1990, 46, 256-262. [CrossRef] [PubMed]

6. Aitken, R.A.; Harper, A.D. Thiophene-Based Quinomethane Analogs. Adv. Heterocycl. Chem. 2017, 123, 169-243. [CrossRef]

7. Kawasaki, T.; Kimachi, T. Sparteine-Mediated Enantioselective [2,3]-Wittig Rearrangement of Allyl ortho-Substituted Benzyl Prenyl Ethers. Tetrahedron 1999, 55, 6847-6862. [CrossRef]

8. Harper, A.D.; Aitken, R.A. The Chemistry of Thieno[c]pyrrolones, Dihydrothieno[c]pyrrolones, and Their Fused Derivatives. Adv. Heterocycl. Chem. 2018, 127, 227-314. [CrossRef]

9. Parella, R.; Babu, S.A. Pd(II)-Catalyzed Arylation and Intramolecular Amidation of $\gamma$-C(sp $\left.{ }^{3}\right)-H$ Bonds: En Route to Arylheteroarylmethane and Pyrrolidone Ring Annulated Furan/Thiophene Scaffolds. J. Org. Chem. 2017, 82, 7123-7150. [CrossRef] [PubMed]

10. Carpenter, A.J.; Chadwick, D.J. The scope and limitations of carboxamide-induced $\beta$-directed metalation of 2-substituted furan, thiophene, and 1-methylpyrrole derivatives. Application of the method to syntheses of 2,3-disubstituted thiophenes and furans. J. Org. Chem. 1985, 50, 4362-4368. [CrossRef]

11. Aitken, R.A.; Harper, A.D.; Slawin, A.M.Z. Synthesis, Structure, and Unusual Reactivity of a Stable 3-(Oxazolidin-2ylidene)thiophen-2-one. J. Org. Chem. 2016, 81, 10527-10531. [CrossRef] [PubMed]

12. Dowd, P.; Choi, S.-C. Free radical ring-expansion leading to novel six- and seven-membered heterocycles. Tetrahedron 1991, 47, 4847-4860. [CrossRef]

13. Hromatka, O.; Binder, D.; Eichinger, K. Über den Mechanismus der Dieckmann-Reaktion von 3-(Methoxycarbonylmethylthio) propionsäuremethylester. Monatsh. Chem. 1973, 104, 1520-1525. [CrossRef]

14. Rossy, P.A.; Hoffmann, W.; Mueller, N. Aromatization of dihydrothiophenes. Thiophenesaccharin: A sweet surprise. J. Org. Chem. 1980, 45, 617-620. [CrossRef]

15. Press, J.B.; Hofmann, C.M.; Safir, S.R. Thiophene systems. 2. Synthesis and chemistry of some 4-alkoxy-3-substituted thiophene derivatives. J. Org. Chem. 1979, 44, 3292-3296. [CrossRef]

16. Purdie, T.; Irvine, J.C. The Alkylation of Sugars. J. Chem. Soc. Trans. 1903, 83, 1023-1037. [CrossRef]

17. Plant, A.; Harder, A.; Mencke, N.; Bertram, H.-J. Synthesis and Anthelmintic Activity of 7-Hydroxy-5-oxo-5H-thieno[3,2-b]pyran6-carboxanilides and -6-thiocarboxanilides. Pestic. Sci. 1996, 48, 351-358. [CrossRef]

18. Schöning, A.; Debbaerdemeker, T.; Zander, M.; Friedrichsen, W. 4,6-Diphenylthieno[2,3-c]furan. Chem. Ber. 1989, 122, 1119-1131. [CrossRef]

19. Gable, R.W.; Laws, M.J.; Schiesser, C.H. N-Butylthiophene-3-carboxamide and 2-Benzylseleno-N-butylthiophene-3-carboxamide at 130K. Acta Crystallogr. Sect. C Cryst. Struct. Commun. 1997, 53, 641-644. [CrossRef]

20. Woodward, R.B.; Eastman, R.H. Tetrahydrothiophene ("thiophane") derivatives. J. Am. Chem. Soc. 1946, 68, 2229-2235. [CrossRef]

21. Sheldrick, G.M. A short history of SHELXL. Acta Crystallogr. A 2008, 64, 112-122. [CrossRef] [PubMed] 